\title{
High-value lipids accumulation by Pavlova pinguis as a response to nitrogen-induced changes
}

\author{
Tomásia Fernandes ${ }^{\mathrm{a}, \mathrm{b}}$, Nereida Cordeiro ${ }^{\mathrm{a}, \mathrm{b}, *}$ \\ ${ }^{a}$ LB3, Faculty of Sciences and Engineering, University of Madeira, Campus Universitário da Penteada, 9020-105, Funchal, Portugal \\ b CIIMAR - Interdisciplinary Centre of Marine and Environmental Research, University of Porto, 4450-208, Matosinhos, Portugal
}

\section{A R T I C L E I N F O}

\section{Keywords:}

Pavlova pinguis

$\mathrm{NO}_{3}^{-}-\mathrm{Nsupply}$

High-value lipids

Biotechnological application

\begin{abstract}
A B S T R A T
The challenges of exploring the potential of microalgal strains for biotechnological applications include the optimization of their cell growth and chemical composition. To overcome this, it is essential to understand the mechanisms that lead to the accumulation of desired products within microalgal cells. In this study, a gradient of nitrogen as nitrate $\left(\mathrm{NO}_{3}^{-}-N\right)$ concentrations was used for the preparation of $P$. pinguis growth medium. The algal growth dynamics, pigments, nutrient uptake, and detailed lipid composition across treatments were assessed. Increasing the $\mathrm{NO}_{3}^{-}-\mathrm{N}$ level led to higher lipid content (21\%), a higher cell uptake rate $\left(0.20 \mathrm{pg} \mathrm{NO}_{3}^{-}-\mathrm{N}\right.$ cell ${ }^{-1}$ $\mathrm{d}^{-1}$ ) and more accumulation of chlorophylls, carotenoids, and high-value lipids. Eicosapentaenoic acid, essential fatty acids, phytol and stigmasterol were the key high-value lipids that were positively influenced by higher $\mathrm{NO}_{3}^{-}-\mathrm{N}$ levels. High $\mathrm{NO}_{3}^{-}-\mathrm{N}$ conditions induced an increase of $54 \%$ in total sterol content, while low $\mathrm{NO}_{3}^{-}-\mathrm{N}$ conditions resulted in increased proportions of saturated fatty acids (66\% more) and decreased proportions of polyunsaturated fatty acids (14\% less). The low $\mathrm{NO}_{3}^{-}-\mathrm{N}$ level also led to higher amounts of monoglyceride (1.60 $\mathrm{mg} \mathrm{g}^{-1} ; 64 \%$ more). The analysis of $P$. pinguis lipids before and after hydrolysis provided an insight into the composition of the esterified lipids across treatments. $\mathrm{NO}_{3}^{-}-\mathrm{N}$ supplementation was revealed to be an effective strategy for enhancing $P$. pinguis lipid composition, for nutraceutical and pharmaceutical industries (high $\mathrm{NO}_{3}^{-}-$ $N$ level). A greater understanding of the $N O_{3}^{-}-N$ uptake and the use efficiency by $P$. pinguis was reached, showing its potential for further biotechnological applications.
\end{abstract}

\section{Introduction}

The search for natural resources that meet the dietary requirements of the growing population without harming the environment is one of the challenges of a bio-based economy [1]. Within such an economy, microalgae are gaining popularity due to their nutrient-rich profiles and sustainability [1]. The main advantages of cultivating these organisms, in a bio-based economy, are avoidance of sludge handling problems (no pesticides and herbicides are used), bio-fixation of carbon dioxide, non-competition for arable lands, ability to readily adapt to changing environmental conditions, and high economic return of algal biomass [2,3].

Microalgal phenotypic plasticity allows the optimization of its chemical composition to target the field of application (e.g. for feedstock fertilizers, energy, bioremediation and nutraceutical markets), whilst decreasing the production costs [3]. Nitrogen is one of the key elements that limits the rate of microalgal cell growth and synthesis of essential cellular components [4]. Thus, the manipulation of this nutrient is often used as a simple approach to increase microalgae productivity for industrial purposes [5-7]. Knowing that nutrient uptake and use efficiency is variable among microalgae, it is crucial to assess the effects of nitrogen supplementation in new microalgal strains that show promise for further biotechnological applications.

The microalgal market is mostly dominated by extremophiles (cyanophyte Arthrospira and chlorophyte Dunaliella) and freshwater (chlorophyte Chlorella) microalgae [8,9]. Given the worldwide scarcity of freshwater and the challenges in replicating extreme environmental conditions, it is crucial to search for new, commercially viable strains that can be grown in seawater [8]. Pavlova species are recognized sources of nutritionally important products $[10,11]$. Within this genus, Pavlova pinguis is an underexploited microalgal species [11,12]. This PUFA-producing microalga is often employed in aquaculture as live feed for penaeid shrimp larvae, bivalve mollusc larvae and freshwater prawn larvae [12]. The metabolite profiling of Pavlova pinguis J.C. Green

\footnotetext{
* Corresponding author. LB3, Faculty of Sciences and Engineering, University of Madeira, Campus Universitário da Penteada, 9020-105, Funchal, Portugal.

E-mail address: ncordeiro@staff.uma.pt (N. Cordeiro).
} 
Table 1

Culture medium composition (f/2-Si medium) used for growing Pavlova pinguis.

\begin{tabular}{ll}
\hline Component & Concentration in final medium $\left(\mathrm{mol} \mathrm{L}^{-1}\right)$ \\
\hline $\mathrm{NaNO}_{3}$ & Variable \\
$\mathrm{NaH}_{2} \mathrm{PO}_{4} \cdot \mathrm{H}_{2} \mathrm{O}$ & $3.62 \times 10^{-5}$ \\
$\mathrm{Na}_{2} \mathrm{SiO}_{3}$ & $1.06 \times 10^{-4}$ \\
$\mathrm{FeCl}_{3} \cdot 6 \mathrm{H}_{2} \mathrm{O}$ & $1.17 \times 10^{-5}$ \\
$\mathrm{Na}_{2} \mathrm{EDTA}_{2} \cdot 2 \mathrm{H}_{2} \mathrm{O}$ & $1.17 \times 10^{-5}$ \\
$\mathrm{MnCl}_{2} \cdot 4 \mathrm{H}_{2} \mathrm{O}$ & $9.10 \times 10^{-7}$ \\
$\mathrm{ZnSO}_{4} \cdot 7 \mathrm{H}_{2} \mathrm{O}$ & $7.65 \times 10^{-8}$ \\
$\mathrm{CoCl}_{2} \cdot 6 \mathrm{H}_{2} \mathrm{O}$ & $4.20 \times 10^{-8}$ \\
$\mathrm{CuSO}_{4} \cdot 5 \mathrm{H}_{2} \mathrm{O}$ & $3.93 \times 10^{-8}$ \\
$\mathrm{Na}_{2} \mathrm{MoO}_{4} \cdot 2 \mathrm{H} \mathrm{O}$ & $2.60 \times 10^{-8}$ \\
$\mathrm{Thiamine} \mathrm{hydrochloride}_{\text {Biotin }}$ & $2.96 \times 10^{-7}$ \\
Cyanocobalamin & $2.05 \times 10^{-9}$ \\
\hline
\end{tabular}

* $\mathrm{NaNO}_{3}$ concentration in final medium was adjusted to 140,939 , and $1752 \mu \mathrm{M}$ for low nitrogen, medium (normal conditions), and high nitrogen growth media, respectively.

showed that this microalgal strain is a potential source of high-value lipids such as polyunsaturated fatty acids (PUFA), long-chain aliphatic alcohols and phytosterols [11]. These lipid sets have recognized therapeutic properties, including antibacterial, antioxidant and anticarcinogenic, as well as cholesterol-lowering properties, making $P$. pinguis suitable for further exploitation in the nutraceutical and pharmaceutical industries [11]. The metabolite characterization of $P$. pinguis in different growth conditions can provide further insights into the regulation of lipid quantity and quality.

Although there are a great number of studies addressing nitrogen supplementation in microalgae composition, their focus is mainly on wastewater remediation and on the lipid production for biofuel purposes [13-16]. Moreover, the few studies addressing the influence of nitrogen supplementation on high-value lipids production by microalgae are mostly performed on a specific lipid set, namely fatty acids, and are constrained to few microalgal species $[17,18]$. P. pinguis have been studied as feed for aquaculture purposes $[19,20]$. However, the knowledge about the influence of different environmental factors, namely nitrogen, on $P$. pinguis growth and high-value lipids accumulation is scarce and crucial to this strain valorization. Thus, to increase the production on high-value lipids and understand its mechanism of accumulation, the Haptophyta $P$. pinguis J.C. Green was assessed for its growth, nitrogen as nitrate $\left(\mathrm{NO}_{3}^{-}-\mathrm{N}\right)$ removal efficiency, lipid accumulation, and detailed composition in different $\mathrm{NO}_{3}^{-}-\mathrm{N}$ levels (low, medium, and high).

\section{Material and methods}

\subsection{Growth and culture conditions}

The non-axenic haptophyte Pavlova pinguis (RCC 1539) was obtained from the Roscoff Culture Collection (RCC), Fig. S1. The f/2-Si medium $[21,22]$ was used as the basal formula (Table 1 ), while nitrogen concentration was changed. Three different levels of nitrogen as nitrate $N_{3}^{-}-N$ were applied: low $N O_{3}^{-}-N$ level (LN) with $140 \pm 2 \mu \mathrm{M}$ $\mathrm{NaNO}_{3}$, medium $\mathrm{NO}_{3}^{-}-N$ level (MN) with $939 \pm 4 \mu \mathrm{M} \mathrm{NaNO}$, and high $\mathrm{NO}_{3}^{-}-\mathrm{N}$ level (HN) with $1752 \pm 24 \mu \mathrm{M} \mathrm{NaNO}$. $\mathrm{LN}$ concentration was chosen to trigger nitrogen limitation without compromising biomass accumulation for the chemical analysis, while HN concentration was chosen to study the effect of excess nitrogen in a non-lethal nitrogen supplementation. For $P$. pinguis cultivation, $100 \mathrm{~mL}$ of starter cultures were inoculated into $1 \mathrm{~L}$ of media, and the initial cell concentration was $8.81 \times 10^{5} \pm 0.23$ cells $\mathrm{mL}^{-1}$, each culture was performed in triplicate. The following growth conditions were applied: $70 \mu \mathrm{mol} \mathrm{m} \mathrm{m}^{-2} \mathrm{~s}^{-1}$ of photon flux, 16:8 h (light: dark) cycles, and a temperature of $25 \pm 1{ }^{\circ} \mathrm{C}$. When cultures reached the early-stationary phase (determined by non-significant differences $(p>0.05)$ on cell concentrations for three consecutive monitoring days), they were harvested using a centrifuge (Z306, HERMLE, Germany) at $3720 \times g$ for $7 \mathrm{~min}$. at room temperature ( $c$. a. $25{ }^{\circ} \mathrm{C}$ ). The obtained pellets were washed using a $0.09 \mathrm{~g} \mathrm{NaCl} \mathrm{L}^{-1}$ solution and centrifuged at $3720 \times g$ for $7 \mathrm{~min}$, this procedure was repeated twice. Then, the pellets were freeze-dried in a Labconco feeze dry system (Freezezone 4.5 , Labconco) at $-50{ }^{\circ} \mathrm{C}$. A linear regression $\left(\mathrm{r}^{2}\right.$ $=0.9988$; Fig. S2) was used to determine daily cell concentration ( $\times 10^{6}$ cells $\mathrm{mL}^{-1}$ ) based on the value of $\mathrm{OD}_{550}$. To perform the linear regression, $P$. pinguis starter cultures were resuspended at various cell concentrations and run through the ultraviolet/visible spectrophotometer (UV-6300PC, VWR) for the OD $_{550}$ measurements using fresh media as blank. The cell concentration was estimated by counting cells with a 0.1 mm deep improved Neubauer haematocytometer (Marienfield Superior) in a light microscope (Olympus BX41). The $\mathrm{OD}_{550}$ was chosen to avoid the range of absorption of photosynthetic pigments as in Samiee-Zafarghandi et al. [23]. The logistic model of Xin et al. [3] was fitted to the observed data using excel add-in solver, in order to describe the microalgal growth.

\section{2. $\mathrm{NO}_{3}^{-}-\mathrm{N}$ determination}

Nitrogen was determined as nitrate $\left(\mathrm{NO}_{3}^{-}-\mathrm{N}\right)$ using the ultraviolet spectrophotometric screening method previously reported by Wan et al. [24], with some modifications. Briefly, a calibration curve $\left(\mathrm{r}^{2}=0.9999\right)$ was drawn using the optical density measured at $220 \mathrm{~nm}\left(\mathrm{OD}_{220}\right)$, plotted against different $\mathrm{NaNO}_{3}$ solution concentrations $(0-4.07 \mathrm{mg}$ $\mathrm{NO}_{3}^{-}-\mathrm{NL}^{-1}$ ). Prior to $\mathrm{NO}_{3}^{-}-\mathrm{N}$ reading in the ultraviolet/visible spectrophotometer (UV-6300PC, VWR), samples were filtered through 0.45 $\mu \mathrm{m}$ membranes, diluted with deionized water and acidified with $1 \mathrm{M}$ $\mathrm{HCl}$.

$\mathrm{NO}_{3}^{-}-\mathrm{N}$ uptake capacity and cell uptake rate were calculated using Equations (1) and (2), where $\mathrm{N}_{\mathrm{i}}$ is the initial $\mathrm{NO}_{3}^{-}-N$ concentration (pg $\left.\mathrm{L}^{-1}\right), \mathrm{N}_{\mathrm{f}}$ is the final $\mathrm{NO}_{3}^{-}-N$ concentration $\left(\mathrm{pg} \mathrm{L}^{-1}\right)$, and $\mathrm{X}$ is cell concentration (cells $\mathrm{L}^{-1}$ ) at time $\mathrm{t}$ (day - d):

$$
\begin{aligned}
& \mathrm{NO}_{3}^{-}-\mathrm{N} \text { uptake capacity }(\%)=\left(\frac{N_{i}-N_{f}}{N_{i}}\right) \times 100 \\
& \text { Cell uptake rate }\left(\mathrm{pg} \mathrm{NO} \mathrm{O}_{3}^{-}-N \text { cell }^{-1} d^{-1}\right)=\frac{\left(N_{i}-N_{f}\right)}{X \times t}
\end{aligned}
$$

\subsection{Pigment determination}

For cellular pigments (chlorophyll $a$, chlorophyll $c_{1}+c_{2}$, and carotenoids) extraction, $10 \mathrm{mg}$ of freeze-dried biomass was extracted with $80 \%$ acetone solution. The samples were vigorously vortexed, ultrasonicated for $90 \mathrm{~min}$, and centrifuged at $4430 \mathrm{xg}$ for $10 \mathrm{~min}$. The supernatant was transferred to pre-chilled $\left(-20^{\circ} \mathrm{C}\right)$ tubes, and pellet was continuously washed (with the cold extraction solution) until the supernatant being colorless. The extracted pigments were filtered through $0.45 \mu \mathrm{m}$ membranes and their absorbance was read in an ultraviolet/ visible spectrophotometer (UV-6300PC, VWR). The amount of chlorophyll $a$ and total carotenoids was calculated according to Chen and Vaidyanathan [25] by equations (3) and (4) where Chl $a$ is the chlorophyll $a\left(\mu \mathrm{g} \mathrm{mL}^{-1}\right)$, and $\mathrm{C}_{\mathrm{t}}$ is the carotenoids $\left(\mu \mathrm{g} \mathrm{mL}^{-1}\right)$ :

Chl $a=12.21 A_{663}-2.81 A_{646}$

$C_{t}=\frac{1000 A_{470}-3.27\left(12.21 A_{663}-2.81 A_{646}\right)-104\left(20.13 A_{646}-5.03 A_{663}\right)}{198}$

Chlorophylls $c_{1}$ and $c_{2}$ determination was performed using the equation described by Jeffrey and Humphrey [26]. Thus, acetone from the supernatant was evaporated on a nitrogen stream and the remaining water was removed by freeze-drying samples. Afterwards, the samples were resuspended on $90 \%$ acetone. The amount of chlorophylls $c_{1}+c_{2}$ 
(Chl $c_{1}+c_{2} ; \mu \mathrm{g} \mathrm{mL}{ }^{-1}$ ), was calculated by the following equation:

Chl $c_{1}+c_{2}=24.36 A_{630}-3.73 A_{664}$

\subsection{Lipid extraction}

Total lipids were estimated from freeze-dried biomass according to Bligh and Dyer [27], with some modifications described by Fernandes et al. [28]. Briefly, to $50 \mathrm{mg}$ of freeze-dried microalgal freeze-dried, 3 $\mathrm{mL}$ of a methanol: chloroform (2:1; v/v) solution was added. After homogenization, a $400 \mu \mathrm{L}$ of a $\mathrm{NaCl}$ saturated solution was added followed by $2 \mathrm{~mL}$ of chloroform and $2 \mathrm{~mL}$ of water. Then, organic phase was removed to pre-weighted tubes, and the remaining biomass continuously washed by addition of chloroform. Extracted organic phase, was dried under a nitrogen stream and gravimetric quantification was performed.

\subsection{Lipid alkaline hydrolysis}

Alkaline hydrolysis was performed on lipid extracts to detect molecules in their esterified forms, according to Santos et al. [29]. $0.5 \mathrm{M}$ $\mathrm{NaOH}$ in aqueous methanol was added to lipid aliquots and the mixtures were heated at $100 \pm 1{ }^{\circ} \mathrm{C}$ for $1 \mathrm{~h}$ under nitrogen atmosphere. Then, the samples were acidified to $\mathrm{pH} 2$ with $1 \mathrm{M} \mathrm{HCl}$, extracted with dichloromethane, dried under a nitrogen stream, and preserved at $-20 \pm 1{ }^{\circ} \mathrm{C}$ until further analysis.

\subsection{Gas chromatography-mass spectrometry (GC-MS) analysis}

To decipher the metabolically induced changes in lipid composition of $P$. pinguis at the different $\mathrm{NO}_{3}^{-}-\mathrm{N}$ levels applied, $P$. pinguis lipid extracts were characterized using GC-MS. Prior to GC-MS analysis, silylation using bis(trimethylsilyl)trifluoroacetamide (BSTFA) of lipid extracts before and after alkaline hydrolysis was performed, as described by Santos et al. [29]. TMS derivatives were analyzed in a gas chromatographer (Agilent HP 6890) equipped with a mass selective detector (Agilent 5973) and a ValcoBon 17704 capillary column VB1 (30 m $\times$ $0.25 \mathrm{~mm}$ inner diameter and $0.25 \mu \mathrm{m}$ film thickness). The chromatographic experimental conditions were as described in Fernandes et al. [11]. The identification of the extracted compounds as TMS derivatives was done by comparison of their mass fragmentation profiles with those in GC-MS Wiley-NIST libraries, published literature [11,30-32], or by injection of authentic standards. The GC-MS analysis was calibrated with pure reference compounds (mannose, trans-ferulic acid, nonadecan-1-ol, eicosan-1-ol, $5 \alpha$-chlolestane, cholesterol (cholest-5-en-3 $\beta$-ol), stigmasterol ( $24 \alpha$-ethylcholesta-5,22E-dien-3 $\beta$-ol), hexadecanoic, and nonadecanoic acids), and the response factor was calculated using tetracosane as the internal standard.

The hypocholesterolaemic/hypercholesterolaemic fatty acids ratio $(\mathrm{H} / \mathrm{H})[33]$ and health promoting index (HPI) [34], were calculated by the following equations:

\subsection{Elemental analysis}

For elemental analysis, Truspec 630-200-200 equipment was used. The combustion furnace temperature was set at $1075{ }^{\circ} \mathrm{C}$ and the afterburner temperature at $850{ }^{\circ} \mathrm{C}$. The detection methods used were the infrared absorption to carbon and the thermal conductivity to nitrogen.

\subsection{Statistical analysis}

The results are expressed as the mean \pm standard deviation (SD) of at least two replicates and reported relative to microalgal dry weight (dw) basis. Statistical analysis of the data was carried out using the software IBM SPSS Statistics 24. Differences between treatments were assessed with Tukey post-hoc analysis, where $p$-values $<0.05$ were considered statistically significant. Within samples, the differences before and after alkaline hydrolysis were evaluated using the $t$-student test, where $p$ values $<0.05$ were considered statistically significant. Metaboanalyst 3.0 was used to perform multivariate analysis [35]. Features were median normalized, $\log _{2}$ transformed and auto scaled before principal component analysis, Pearson's correlation analysis and hierarchical clustering. For hierarchical clustering heat maps, Euclidean clustering distance and the ward clustering method were used.

\section{Results and discussion}

\subsection{Microalgal growth, $\mathrm{NO}_{3}^{-}-\mathrm{N}$ removal, and chemical composition}

The plots of Pavlova pinguis growth and medium total $\mathrm{NO}_{3}^{-}-\mathrm{N}$ (Fig. 1) show that $\mathrm{NO}_{3}^{-}-\mathrm{N}$ concentrations decreased over time, with a concomitant increase in Pavlova pinguis cell concentration. The final cell concentration of $P$. pinguis in low (LN), medium (MN) and high (HN) $\mathrm{NO}_{3}^{-}-N$ levels were $3.37 \times 10^{6}, 1.17 \times 10^{7}$ and $1.17 \times 10^{7}$ cells $\mathrm{mL}^{-1}$, respectively. The similar $(p<0.05)$ cell concentrations observed for the $\mathrm{MN}$ and $\mathrm{HN}$ treatments could be from at $\mathrm{HN}$ conditions $i$ ) microalgal cell division slows down as light becomes limiting, and/or ii) the primary growth limiting nutrient may be a different one from nitrogen. While in LN treatment, nitrogen seems to be the primary growth limiting factor. In the present study the concentrations of $\mathrm{NO}_{3}^{-}-\mathrm{N}$ analyzed were 1.96 (LN), 13.15 (MN), and $24.53(\mathrm{HN}) \mathrm{mg} \mathrm{L}^{-1}$.

Previous studies have reported an increase in microalgal final cell concentration with the nitrogen content in culture medium. According to Sivaramakrishnan and Incharoensakdi [36] an increase in final cell concentration was observed when increasing sodium nitrate concentrations from 0 to $3 \mathrm{~g} \mathrm{~L}^{-1}$ for Scenedesmus sp., Chlorella sp., and Chlamydomonas sp. using BG-11 as basal medium. Zakariah et al. [37] reported for Chlorella sorokiniana an increase in final cell concentration when nitrogen concentration when up from 29.80 to $43.65 \mathrm{mg} \mathrm{NO}_{3}^{-}-$ $\mathrm{NL}^{-1}$ using Bolds basal medium. However, these microalgae are from freshwater environment and belong to a distinct phylum (Chlorophyta) than P. pinguis (Haptophyta). Zarrinmehr et al. [38] studied the effect of nitrogen concentration on a marine Haptophyta (Isochrysis galbana) growth, and observed the same increasing trend of cell concentration
$H P I=\sum U F A /[C 12: 0+(4 \times C 14: 0)+C 16: 0]$

In Equation (7) UFA stands for unsaturated fatty acids. with nitrogen concentration from 72 to $144 \mathrm{mg} \mathrm{L}^{-1}$. Nevertheless, when $\mathrm{NO}_{3}^{-}-N \mathrm{~L}^{-1}$ was higher than 144 , an inhibitory effect was observed. It is important to mention that the study performed on Isochrysis galbana used Walne's as basal growth medium, presenting different nutrient concentrations and nutrient ratios than $\mathrm{f} / 2$-Si medium (used in the present study).

$P$. pinguis reached the early-stationary phase at different cultivation 
a)

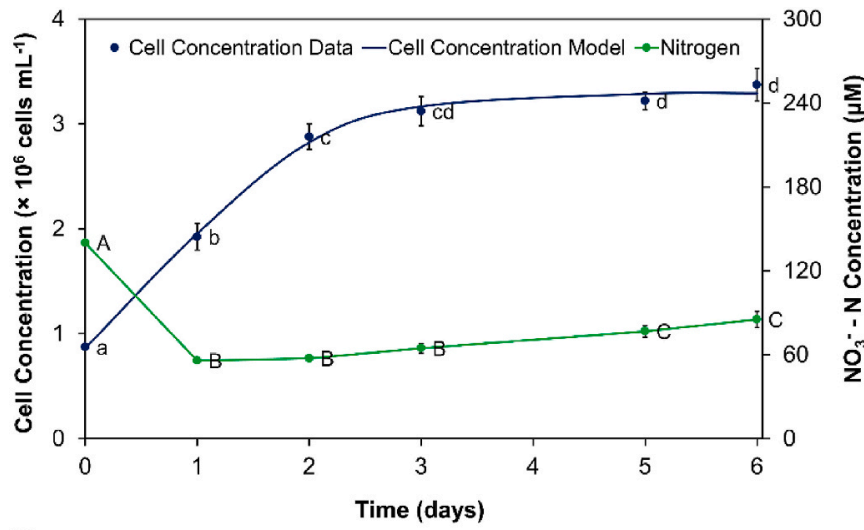

b)

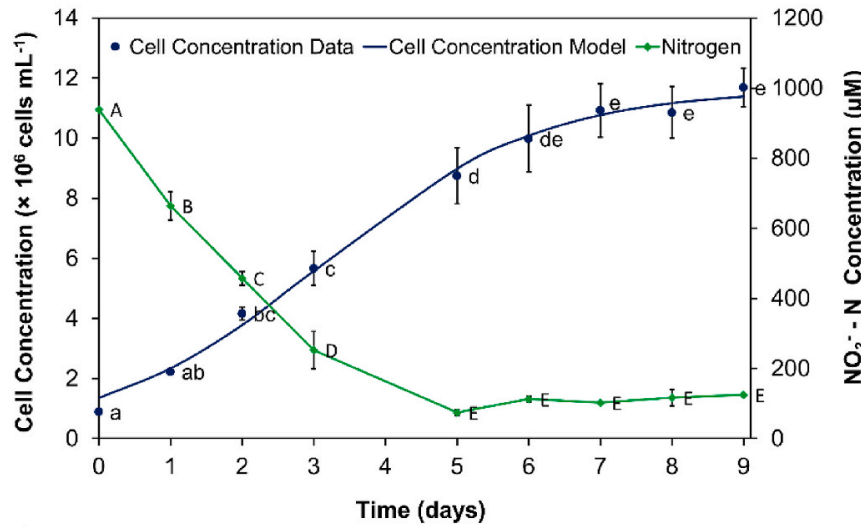

c)

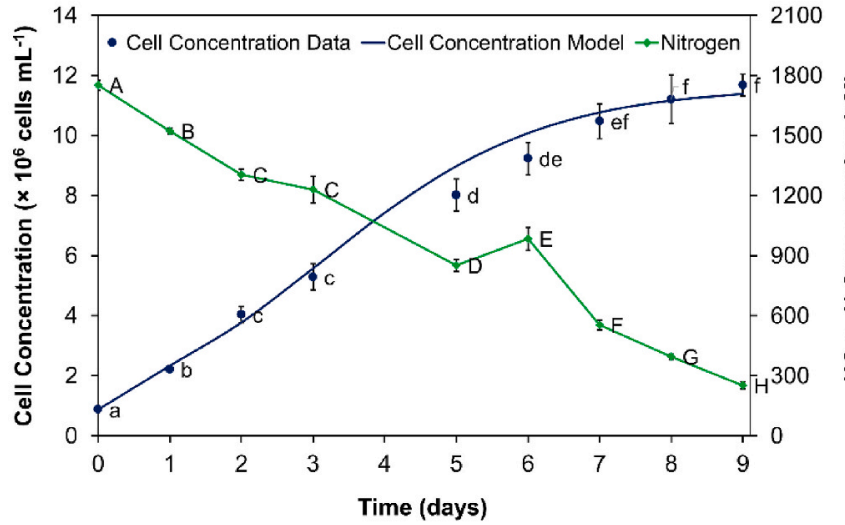

Fig. 1. Growth curves and nitrogen assessed as nitrate $\left(\mathrm{N}-\mathrm{NO}_{3}^{-}\right)$concentration in Pavlova pinguis growth medium throughout the cultivation days. a) low nitrogen level, b) medium nitrogen level, c) high nitrogen level. Data are expressed as mean \pm standard deviation $(n=3)$. Differences in cell concentration and total nitrogen among cultivation days were assessed using analysis of variance followed by Tukey's post-hoc analysis and are represented by different uppercase letters for total nitrogen, and different lowercase letters for cell concentration $(p<0.05)$. Determination coefficients $\left(r^{2}\right)$ for logistic growth models were higher than 0.95 .

times. The cells in the $\mathrm{LN}$ treatment showed a gradual increase until day 3 , whereas those in both the MN and $\mathrm{HN}$ treatments continued to increase until day 7. In both $\mathrm{LN}$ and $\mathrm{MN}$ conditions, total $\mathrm{NO}_{3}^{-}-\mathrm{N}$ reached its residual value and plateau stage before microalgae reached the earlystationary phase. It is known that cell division stops when no nitrogen is available to be assimilated into proteins, needed to maintain growth, thus the former behavior is explained [39]. Although cell concentration showed similar behavior for $P$. pinguis grown in $\mathrm{MN}$ and $\mathrm{HN}$ conditions, $\mathrm{NO}_{3}^{-}-\mathrm{N}$ content in $\mathrm{HN}$ growth conditions did not reach a plateau stage.
This can be explained by the luxury storage of nitrogen in $P$. pinguis microalgal cells, which can occur in high nitrogen environments [40].

The effect of $\mathrm{NO}_{3}^{-}-\mathrm{N}$ level on $\mathrm{P}$. pinguis $\mathrm{NO}_{3}^{-}-\mathrm{N}$ uptake rate and removal efficiency, intracellular nutrient stoichiometry, lipid content, final cell concentration, and pigments were studied (Table 2). In HN cultures, the highest cell uptake rates $\left(0.20 \mathrm{pg} \mathrm{NO}_{3}^{-}-N\right.$ cell $\left.^{-1} \mathrm{~d}^{-1}\right)$ and $\mathrm{NO}_{3}^{-}-\mathrm{N}$ removal (86\%) were obtained. Meanwhile, the lowest values for cell uptake rate $\left(0.04 \mathrm{pg} \mathrm{NO}_{3}^{-}-\mathrm{N}\right.$ cell $\left.^{-1} \mathrm{~d}^{-1}\right)$ and $\mathrm{NO}_{3}^{-}-\mathrm{N}$ removal (39\%) were observed in $P$. pinguis microalgal cells grown in LN conditions. These findings are in accordance with Tantanasarit et al. [41], which reported that the marine diatom Chaetoceros calcitrans can efficiently increase the uptake rate of inorganic nutrients at higher nutrient levels, assimilating them for binary fission. This can indicate that $\mathrm{NO}_{3}^{-}-$ $N$ acquisition by $P$. pinguis is positively regulated by increasing $\mathrm{NO}_{3}^{-}-\mathrm{N}$ levels, an assumption that has already been verified for other microalgae $[3,42]$. Varying nitrogen removal efficiencies were also observed for a freshwater microalga (Scenedesmus) grown in different nitrogen supplementations [3]. In contrast to the present study, nitrogen inputs led to a decrease in nitrogen removal efficiency (from $>99$ to 45\%). This variability could be attributed not only to nitrogen supplies but also to the ratio of nitrogen to the other nutrients present in the microalgal growth medium, which is known to limit nutrient acquisition by cells. Moreover, nutrient uptake and use efficiency is microalga species-specific.

Daneshvar et al. [43] studied the nitrate removal efficiency for Chlorella vulgaris against several macro and micronutrients concentrations, nitrate concentration, inoculum sizes, initial $\mathrm{pH}$ of the medium, and different concentrations of sea salt and sodium chloride, and concluded that nitrate removal efficiency can be improved by manipulating other cultivation conditions besides nitrogen concentration. Moreover, Fan et al. [44] reported that nitrogen uptake rates vary among microalgal species mostly due to their different metabolic processes that limits not only their biochemical composition but also their nutrient acquisition and assimilation abilities. In the previous study, the nitrogen to phosphorus ratio had a substantial effect on nutrients removal by microalga.

The changes in $\mathrm{NO}_{3}^{-}-\mathrm{N}$ uptake capacity reflected on $P$. pinguis intracellular stoichiometry (Table 2), significantly affecting the carbon and nitrogen molar ratio $(\mathrm{C} / \mathrm{N})$, which decreased by $68 \%$ from $\mathrm{LN}$ to $\mathrm{HN}$ conditions. This trend indicates that when the $\mathrm{NO}_{3}^{-}-\mathrm{N}$ level is high, $P$. pinguis microalgal cells accumulate more nitrogen in their biomass (proteins) and less carbon-rich metabolites (carbohydrates and lipids)

Table 2

Final cell density, nitrogen uptake, pigments, and elemental analysis of Pavlova pinguis grown under different nitrogen supplementation.

\begin{tabular}{|c|c|c|c|}
\hline & $\begin{array}{l}\text { Low } \\
\text { Nitrogen }\end{array}$ & $\begin{array}{l}\text { Medium } \\
\text { Nitrogen }\end{array}$ & $\begin{array}{l}\text { High } \\
\text { Nitrogen }\end{array}$ \\
\hline $\begin{array}{l}\text { Final cell density }\left(\times 10^{6} \text { cells }\right. \\
\left.\mathrm{mL}^{-1}\right)\end{array}$ & $3.37 \pm 0.15^{\mathrm{a}}$ & $11.69 \pm 0.64^{b}$ & $11.68 \pm 0.36^{b}$ \\
\hline Nitrogen uptake ability (\%) & $39.19 \pm 3.45^{\mathrm{a}}$ & $85.35 \pm 2.38^{\mathrm{b}}$ & $85.62 \pm 1.32^{\mathrm{b}}$ \\
\hline $\begin{array}{l}\text { Cell uptake rate (pg } \mathrm{NO}_{3}^{-}-N \\
\text { cell }^{-1} \mathrm{~d}^{-1} \text { ) }\end{array}$ & $0.04 \pm 0.00^{\mathrm{a}}$ & $0.11 \pm 0.01^{\mathrm{b}}$ & $0.20 \pm 0.02^{\mathrm{c}}$ \\
\hline Chl $a\left(\mathrm{mg} \mathrm{g}^{-1} \mathrm{dw}\right)$ & $0.31 \pm 0.01^{\mathrm{a}}$ & $3.91 \pm 0.65^{\mathrm{b}}$ & $11.08 \pm 0.54^{\mathrm{c}}$ \\
\hline Chl $c_{1}+c_{2}\left(\mathrm{mg} \mathrm{g}^{-1} \mathrm{dw}\right)$ & $0.29 \pm 0.05^{\mathrm{a}}$ & $0.92 \pm 0.15^{\mathrm{b}}$ & $1.79 \pm 0.17^{\mathrm{c}}$ \\
\hline $\mathrm{C}_{\mathrm{t}}\left(\mathrm{mg} \mathrm{g}^{-1} \mathrm{dw}\right)$ & $0.05 \pm 0.00^{\mathrm{a}}$ & $0.98 \pm 0.06^{\mathrm{b}}$ & $2.91 \pm 0.15^{c}$ \\
\hline Lipid $(\% \mathrm{dw})$ & $12.56 \pm 0.89^{\mathrm{a}}$ & $15.64 \pm 0.36^{\mathrm{b}}$ & $21.25 \pm 0.82^{\mathrm{c}}$ \\
\hline $\mathrm{C}(\% \mathrm{dw})$ & $12.22 \pm 0.77^{\mathrm{a}}$ & $17.57 \pm 0.15^{\mathrm{b}}$ & $31.81 \pm 0.31^{\mathrm{c}}$ \\
\hline $\mathrm{N}(\% \mathrm{dw})$ & $0.67 \pm 0.07^{\mathrm{a}}$ & $1.68 \pm 0.03^{\mathrm{b}}$ & $5.52 \pm 0.22^{\mathrm{c}}$ \\
\hline $\mathrm{H}(\% \mathrm{dw})$ & $3.36 \pm 0.19^{\mathrm{a}}$ & $3.60 \pm 0.62^{\mathrm{a}}$ & $4.78 \pm 0.28^{\mathrm{b}}$ \\
\hline $\mathrm{C} / \mathrm{N}$ (mol:mol) & $20.86 \pm 0.89^{\mathrm{a}}$ & $12.19 \pm 0.12^{\mathrm{b}}$ & $6.72 \pm 0.22^{c}$ \\
\hline
\end{tabular}

dw: dry weight. Each value is the mean \pm standard deviation $(n \geq 2)$. Different letters in the same column indicate significant differences $(p<0.05)$, based on analysis of variance followed by Tukey's post hoc analysis. Sulphur was not detected. Chl $a$-Chlorophyll $a$; Chl $c_{1}+c_{2}$ - Chlorophylls $c_{1}+c_{2}$; $\mathrm{C}_{\mathrm{t}}$ - total carotenoids; $\mathrm{C}$ - Carbon; $\mathrm{N}$ - Nitrogen; $\mathrm{H}$ - Hydrogen. 


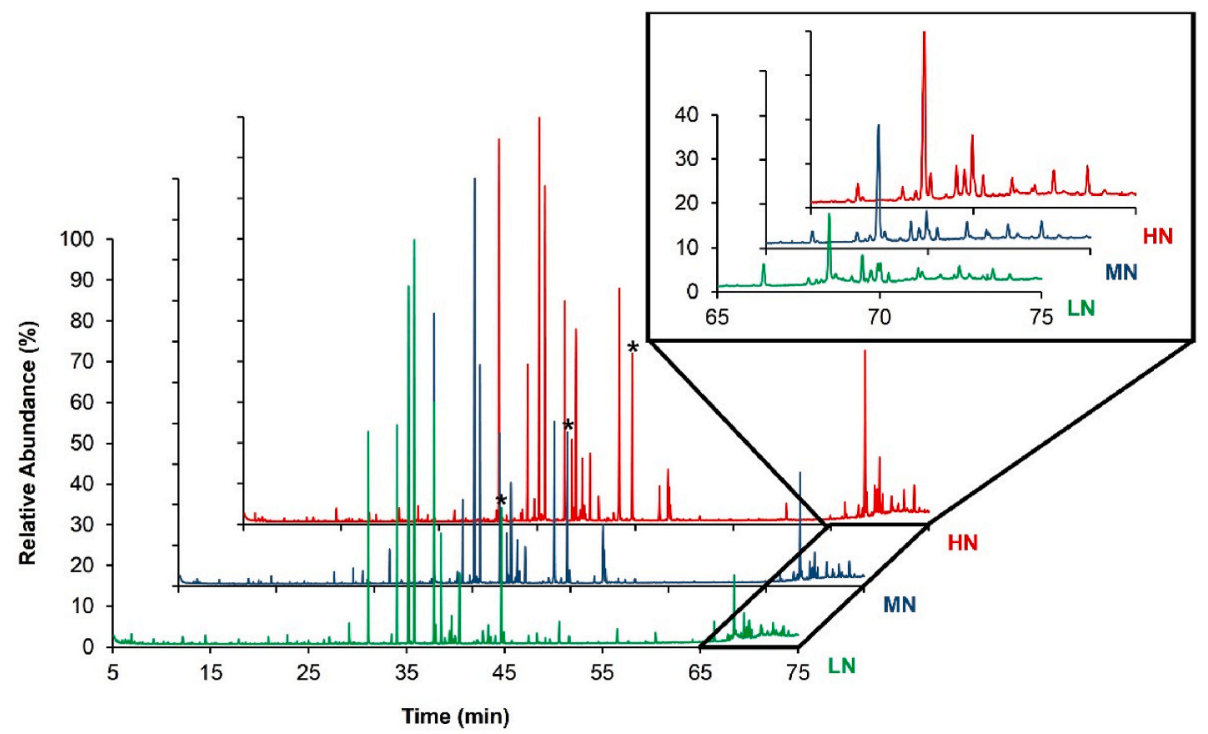

Fig. 2. Chromatograms obtained for lipid extracts of Pavlova pinguis grown in low (LN), medium (MN) and high (HN) nitrogen level, before alkaline hydrolysis. * Internal standard (Tetracosane).

[28,45]. The lipid content ranged from 12.56 to $21.25 \%$, with the highest value being obtained in microalgae grown in $\mathrm{HN}$ conditions. Thus, the accumulation of carbon-rich metabolites in LN conditions was not from lipids but from carbohydrates, suggesting that this macromolecular pool is the main carbon reservoir for $P$. pinguis microalgal cells under LN conditions.

Food's rich in chlorophyll and carotenoids are considered to be very nutritious as their consumption provides recognized health benefits [46]. In chlorophylls, the presence of the heme group is beneficial for the production of red blood cells, while carotenoids are known as chemoprotective agents against several diseases like cancer and diabetes [46]. In this study, $P$. pinguis accumulated these pigments at high $\mathrm{NO}_{3}^{-}-\mathrm{N}$ conditions: 11.08 (chlorophyll $a$ ); 1.79 (chlorophylls $c_{1}+c_{2}$ ); and 2.91 (total carotenoids) $\mathrm{mg} \mathrm{g}^{-1}$ (Table 2). Thus, at HN conditions, $P$. pinguis show a great industrial potential for healthcare and cosmetic industries.

\subsection{GC-MS metabolite profile}

The GC chromatographic fingerprints of $P$. pinguis cultured under different $\mathrm{NO}_{3}^{-}-\mathrm{N}$ conditions are displayed in Fig. 2. Through this figure, it is possible to visualize relative changes of GC spectra obtained for $P$. pinguis grown in different initial $\mathrm{NO}_{3}^{-}-\mathrm{N}$ concentrations. These differences suggest that changes in lipid's quality occurred with the $\mathrm{NO}_{3}^{-}-\mathrm{N}$ supply. In addition, the increase of sterols in $P$. pinguis lipid composition becomes obvious by an increase in GC peaks heights in the region commonly attributed to sterols (amplified in Fig. 2) from LN to $\mathrm{HN}$ conditions. Moreover, at a first sight it seems that $P$. pinguis cultured grown in LN conditions presents a poorest lipid composition verified before hydrolysis when compared with the other treatments. This is further corroborated by the number of identified compounds before hydrolysis for LN conditions (54), and for the remaining treatments, MN (63) and HN (59). The highest intensity peak varied with treatments applied corresponding to hexadecanoic acid (C16:0) in $P$. pinguis grown

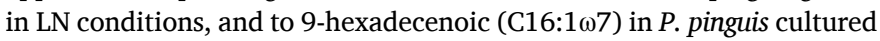
in $\mathrm{MN}$ and $\mathrm{HN}$ conditions. These observations suggest that a lipid remodeling did occur in $P$. pinguis as a response to different initial $\mathrm{NO}_{3}^{-}-$ $N$ concentrations.

\subsubsection{Fatty acids}

Fatty acids were the major components of $P$. pinguis extracted lipids, comprising $63-76 \%$ of the total identified compounds (Table 3 ). The

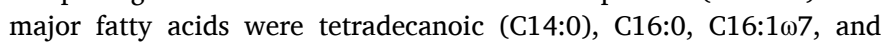

5,8,11,14,17-eicosapentaenoic (EPA - C20:5 accounted for more than $30 \%$ of the total, under different $\mathrm{NO}_{3}^{-}-\mathrm{N}$ conditions. With an increasing $\mathrm{NO}_{3}^{-}-\mathrm{N}$ level, the quantities and types of fatty acids varied significantly $(p<0.05)$, before hydrolysis (BH; free fatty acids) and after alkaline hydrolysis ( $\mathrm{AH}$; esterified fatty acids), Table 3. The maximum total fatty acid content was observed in HN conditions (BH: $95.57 \mathrm{mg} \mathrm{g}^{-1}$; $\mathrm{AH}$ : $141.62 \mathrm{mg} \mathrm{g}^{-1}$ ), while the lowest total fatty acid content was verified in $\mathrm{LN}$ conditions (BH: $46.82 \mathrm{mg} \mathrm{g}^{-1}$; AH: $71.54 \mathrm{mg} \mathrm{g}^{-1}$ ).

Saturated fatty acids are often associated with storage lipids of microalgae, while PUFA are mostly present in structural lipids [38]. At LN conditions $P$. pinguis presented the highest proportion of saturated fatty acids (SFA), $40-49 \%$ of total identified compounds, and the lowest PUFA proportion, $10-11 \%$ of total identified compounds. Additionally, at LN conditions the lowest chlorophylls content (Table 2) was observed. These observations suggest that under nitrogen deprived conditions $P$. pinguis displace its efforts for storing nitrogen in chlorophylls (nitrogen-rich compounds) to maintain photosynthetic activity, whereas the fixed carbon is stored in neutral lipids rich in SFA (e.g. triacylglycerols). Previous studies [38,47] performed for a haptophyte (Isochrysis galbana) have reported that under nitrogen-depleted conditions the expression of PUFA-specific enzymes genes (desaturases and elongases) was not positively affected, in contrast to nitrogen-replete conditions. The expression of these genes is important for the synthesis of PUFA in microalgae.

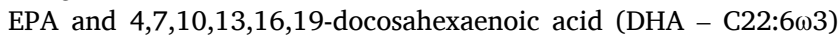
have well-established promoting effects on human health (e.g. reduce the risk of cardiovascular disease, anti-inflammatory, and neuroprotective) and understanding the conditions that induce the synthesis of these fatty acids by microalgae is essential to further explore the uses of these compounds for the food and pharmaceutical industries. Through Fig. 3 it is possible to visualize a positive effect of increasing initial $\mathrm{NO}_{3}^{-}-N$ levels on the sum of EPA and DHA (EPA + DHA) by $P$. pinguis, indicating that a high $\mathrm{NO}_{3}^{-}-\mathrm{N}$ supply is more suitable for high-value lipids accumulation by $P$. pinguis. The highest DHA + EPA was obtained at $\mathrm{HN}$ conditions after hydrolysis comprising $18.48 \mathrm{mg} \mathrm{g}^{-1}$ $\mathrm{dw}$. The trend verified in the present study for EPA + DHA was also described for Nannochloropsis species [7,48], where nutrient-limiting conditions was suggested to reduce the synthesis of LC-PUFA (EPA).

Both hypocholesterolaemic/hypercholesterolaemic fatty acids ratio $(\mathrm{H} / \mathrm{H})$ and health-promoting index (HPI) reflect the effect of the fatty acid composition on cardiovascular diseases [34]. For these nutritional 
Table 3

Lipid profile ( $\mathrm{mg} \mathrm{g}^{-1}$ of dry microalgal weight) of Pavlova pinguis grown in three different nitrogen levels before (BH) and after (AH) alkaline hydrolysis.

\begin{tabular}{|c|c|c|c|c|c|c|c|}
\hline \multirow[t]{2}{*}{$\mathrm{N}^{\mathrm{o}}$} & & \multicolumn{2}{|l|}{ Low Nitrogen } & \multicolumn{2}{|l|}{ Medium Nitrogen } & \multicolumn{2}{|l|}{ High Nitrogen } \\
\hline & & BH & $\mathrm{AH}$ & BH & $\mathrm{AH}$ & BH & $\mathrm{AH}$ \\
\hline & Fatty acids & $46.82 \pm 0.69^{a A}$ & $71.54 \pm 3.04^{b 1}$ & $91.60 \pm 2.72^{a B}$ & $115.95 \pm 2.17^{b 2}$ & $95.57 \pm 0.30^{a C}$ & $141.62 \pm 2.24^{b 3}$ \\
\hline & Saturated & $29.78 \pm 0.48^{a A}$ & $46.93 \pm 1.88^{b 1}$ & $39.56 \pm 1.44^{a B}$ & $55.55 \pm 1.10^{b 2}$ & $42.87 \pm 0.24^{a C}$ & $64.91 \pm 1.88^{b 3}$ \\
\hline 1 & Nonanoic acid & $1.04 \pm 0.01^{\mathrm{aA}}$ & $1.55 \pm 0.01^{\mathrm{b} 1}$ & $1.55 \pm 0.00^{\mathrm{aB}}$ & $2.01 \pm 0.00^{\mathrm{b} 2}$ & $1.55 \pm 0.02^{\mathrm{aB}}$ & $2.09 \pm 0.01^{\mathrm{b} 3}$ \\
\hline 3 & Decanoic acid & $1.04 \pm 0.01^{\mathrm{aA}}$ & $1.53 \pm 0.00^{\mathrm{b} 1}$ & $1.55 \pm 0.01^{\mathrm{aB}}$ & $2.04 \pm 0.01^{\mathrm{b} 2}$ & $1.56 \pm 0.01^{\mathrm{aB}}$ & $2.09 \pm 0.01^{\mathrm{b} 3}$ \\
\hline 6 & Undecanoic acid & $1.03 \pm 0.01^{\mathrm{A}}$ & n.d. & $1.56 \pm 0.01^{\mathrm{B}}$ & n.d. & $1.55 \pm 0.02^{\mathrm{B}}$ & n.d. \\
\hline 8 & Dodecanoic acid & $1.04 \pm 0.00^{\mathrm{aA}}$ & $1.54 \pm 0.01^{\mathrm{b} 1}$ & $1.56 \pm 0.01^{\mathrm{aB}}$ & $2.06 \pm 0.01^{\mathrm{b} 2}$ & $1.54 \pm 0.02^{\mathrm{aB}}$ & $2.12 \pm 0.02^{\mathrm{b} 3}$ \\
\hline 12 & Tetradecanoic acid & $3.92 \pm 0.32^{\mathrm{aA}}$ & $7.74 \pm 0.49^{\mathrm{b} 1}$ & $5.73 \pm 0.86^{\mathrm{aB}}$ & $11.43 \pm 0.52^{\mathrm{b} 2}$ & $7.71 \pm 0.18^{\mathrm{aC}}$ & $16.96 \pm 0.43^{\mathrm{b} 3}$ \\
\hline 13 & Pentadecanoic acid & $1.14 \pm 0.01^{\mathrm{aA}}$ & $1.72 \pm 0.02^{\mathrm{b} 1}$ & $1.72 \pm 0.02^{\mathrm{aB}}$ & $2.34 \pm 0.02^{\mathrm{b} 2}$ & $1.68 \pm 0.01^{\mathrm{aC}}$ & $2.39 \pm 0.02^{\mathrm{b} 3}$ \\
\hline 21 & Hexadecanoic acid & $6.15 \pm 0.28^{\mathrm{aA}}$ & $11.49 \pm 0.85^{\mathrm{b} 1}$ & $5.41 \pm 0.55^{\mathrm{aA}}$ & $9.12 \pm 0.36^{\mathrm{b} 1}$ & $6.32 \pm 0.18^{\mathrm{aB}}$ & $10.80 \pm 1.40^{\mathrm{b} 1}$ \\
\hline 23 & Heptadecanoic acid & $1.30 \pm 0.06^{\mathrm{aA}}$ & $1.69 \pm 0.03^{\mathrm{b} 1}$ & $1.79 \pm 0.05^{\mathrm{aB}}$ & $2.17 \pm 0.00^{\mathrm{b} 2}$ & $1.82 \pm 0.03^{\mathrm{aB}}$ & $2.26 \pm 0.03^{\mathrm{b} 3}$ \\
\hline 31 & Octadecanoic acid & $1.99 \pm 0.04^{\mathrm{aA}}$ & $3.55 \pm 0.43^{\mathrm{b} 1}$ & $2.30 \pm 0.15^{\mathrm{aB}}$ & $3.31 \pm 0.06^{\mathrm{b} 1,2}$ & $2.70 \pm 0.03^{\mathrm{aC}}$ & $4.49 \pm 0.43^{\mathrm{b} 2}$ \\
\hline 36 & Eicosanoic acid & $2.20 \pm 0.02^{\mathrm{aA}}$ & $3.22 \pm 0.02^{\mathrm{b} 1}$ & $3.26 \pm 0.01^{\mathrm{aB}}$ & $4.19 \pm 0.01^{\mathrm{b} 2}$ & $3.25 \pm 0.03^{\mathrm{aB}}$ & $4.33 \pm 0.02^{\mathrm{b} 3}$ \\
\hline 43 & Docosanoic acid & $2.27 \pm 0.03^{\mathrm{aA}}$ & $3.27 \pm 0.02^{\mathrm{b} 1}$ & $3.33 \pm 0.02^{\mathrm{aB}}$ & $4.26 \pm 0.02^{\mathrm{b} 2}$ & $3.33 \pm 0.03^{\mathrm{aB}}$ & $4.37 \pm 0.01^{\mathrm{b} 3}$ \\
\hline 45 & Tetracosanoic acid & $2.19 \pm 0.01^{\mathrm{aA}}$ & $3.19 \pm 0.01^{\mathrm{b} 1}$ & $3.26 \pm 0.01^{\mathrm{aB}}$ & $4.17 \pm 0.02^{\mathrm{b} 2}$ & $3.25 \pm 0.04^{\mathrm{aB}}$ & $4.29 \pm 0.00^{\mathrm{b} 3}$ \\
\hline 50 & Octacosanoic acid & $2.20 \pm 0.01^{\mathrm{aA}}$ & $3.20 \pm 0.00^{\mathrm{b} 1}$ & $3.26 \pm 0.01^{\mathrm{aB}}$ & $4.17 \pm 0.01^{\mathrm{b} 2}$ & $3.26 \pm 0.04^{\mathrm{aB}}$ & $4.29 \pm 0.00^{\mathrm{b} 3}$ \\
\hline \multirow[t]{2}{*}{60} & Triacontanoic acid & $2.27 \pm 0.03^{\mathrm{aA}}$ & $3.23 \pm 0.01^{\mathrm{b} 1}$ & $3.29 \pm 0.01^{\mathrm{aB}}$ & $4.28 \pm 0.04^{\mathrm{b} 2}$ & $3.35 \pm 0.04^{\mathrm{aC}}$ & $4.43 \pm 0.09^{\mathrm{b} 2}$ \\
\hline & Monounsaturated & $8.91 \pm 0.25^{a A}$ & $14.90 \pm 1.07^{b 1}$ & $16.87 \pm 1.06^{a B}$ & $23.96 \pm 0.64^{b 2}$ & $15.83 \pm 0.41^{a B}$ & $25.83 \pm 0.20^{b 3}$ \\
\hline 11 & 9-Tetradecenoic acid & n.d. & $1.54 \pm 0.00^{\mathrm{a}}$ & $1.56 \pm 0.01^{\mathrm{aA}}$ & $2.00 \pm 0.01^{\mathrm{b} 2}$ & $1.57 \pm 0.02^{\mathrm{aA}}$ & $2.10 \pm 0.03^{\mathrm{b} 3}$ \\
\hline 18 & 9-Hexadecenoic acid ${ }^{\mathrm{a}}$ & $5.36 \pm 0.25^{\mathrm{aA}}$ & $8.07 \pm 0.84^{\mathrm{b} 1}$ & $9.90 \pm 0.94^{\mathrm{aB}}$ & $15.24 \pm 0.56^{\mathrm{b} 2}$ & $8.92 \pm 0.19^{\mathrm{aB}}$ & $16.34 \pm 0.16^{\mathrm{b} 2}$ \\
\hline 19 & 7-Hexadecenoic acid & $1.06 \pm 0.00^{\mathrm{aA}}$ & $1.55 \pm 0.01^{\mathrm{b} 1}$ & $1.65 \pm 0.05^{\mathrm{aB}}$ & $2.09 \pm 0.01^{\mathrm{b} 2}$ & $1.62 \pm 0.02^{\mathrm{aB}}$ & $2.20 \pm 0.01^{\mathrm{b} 3}$ \\
\hline 30 & 11-Octadecenoic acid & $1.10 \pm 0.01^{\mathrm{aA}}$ & $1.68 \pm 0.04^{\mathrm{b} 1}$ & $1.74 \pm 0.04^{\mathrm{aB}}$ & $2.21 \pm 0.03^{\mathrm{b} 2}$ & $1.78 \pm 0.04^{\mathrm{aB}}$ & $2.49 \pm 0.12^{\mathrm{b} 3}$ \\
\hline \multirow[t]{2}{*}{29} & 9-Octadecenoic acid & $1.39 \pm 0.01^{\mathrm{aA}}$ & $2.06 \pm 0.19^{\mathrm{b} 1}$ & $2.01 \pm 0.29^{\mathrm{aB}}$ & $2.42 \pm 0.04^{\mathrm{a} 2}$ & $1.94 \pm 0.22^{\mathrm{aB}}$ & $2.70 \pm 0.07^{\mathrm{b} 2}$ \\
\hline & Polyunsaturated & $8.12 \pm 0.06^{a A}$ & $9.71 \pm 0.09^{b 1}$ & $35.17 \pm 0.52^{a B}$ & $36.44 \pm 0.43^{b 2}$ & $36.87 \pm 0.42^{a C}$ & $50.89 \pm 0.24^{b 3}$ \\
\hline 15 & 7,12-Hexadienoic acid & n.d. & n.d. & $1.58 \pm 0.06^{\mathrm{A}}$ & n.d. & $1.59 \pm 0.01^{\mathrm{aA}}$ & $2.10 \pm 0.06^{\mathrm{b}}$ \\
\hline 16 & 7,10-Hexadecadienoic acid & n.d. & n.d. & $1.67 \pm 0.13^{\mathrm{aA}}$ & $2.03 \pm 0.08^{\mathrm{b} 1}$ & $1.76 \pm 0.13^{\mathrm{aA}}$ & $2.37 \pm 0.18^{\mathrm{b} 2}$ \\
\hline 17 & $7,10,13$-Hexadecatrienoic acid & n.d. & n.d. & $1.61 \pm 0.06^{\mathrm{A}}$ & n.d. & $1.60 \pm 0.07^{\mathrm{aA}}$ & $2.17 \pm 0.11^{\mathrm{b}}$ \\
\hline 20 & Methyl-4,7,10,13-hexadecatetraenoate & n.d. & n.d. & $3.28 \pm 0.06^{\mathrm{A}}$ & n.d. & $3.27 \pm 0.04^{\mathrm{aA}}$ & $4.31 \pm 0.01^{\mathrm{b}}$ \\
\hline 27 & 9,12-Octadecadienoic acid & $1.21 \pm 0.01^{\mathrm{aA}}$ & $3.22 \pm 0.05^{\mathrm{b} 1}$ & $3.25 \pm 0.15^{\mathrm{aB}}$ & $4.08 \pm 0.02^{\mathrm{b} 2}$ & $3.23 \pm 0.03^{\mathrm{aB}}$ & $4.35 \pm 0.08^{\mathrm{b} 3}$ \\
\hline 28 & $9,12,15$-Octadecatrienoic acid & n.d. & n.d. & $3.28 \pm 0.03^{\mathrm{aA}}$ & $4.21 \pm 0.01^{\mathrm{b} 1}$ & $3.35 \pm 0.03^{\mathrm{aB}}$ & $4.45 \pm 0.01^{\mathrm{b} 2}$ \\
\hline 25 & $3,6,9,12,15$-Octadecapentaenoic acid & n.d. & n.d. & $1.67 \pm 0.01^{\mathrm{aA}}$ & $2.14 \pm 0.01^{\mathrm{b} 1}$ & $1.71 \pm 0.01^{\mathrm{aB}}$ & $2.32 \pm 0.01^{\mathrm{b} 2}$ \\
\hline 32 & 5,8,11,14,17-Eicosapentaenoic acid & $2.43 \pm 0.03^{\mathrm{aA}}$ & $3.28 \pm 0.03^{\mathrm{b} 1}$ & $6.75 \pm 0.55^{\mathrm{aB}}$ & $8.47 \pm 0.20^{\mathrm{b} 2}$ & $8.28 \pm 0.06^{\mathrm{aC}}$ & $12.10 \pm 0.06^{\mathrm{b} 3}$ \\
\hline 38 & 7,10,13,16,19-docosapentaenoic acid & $2.17 \pm 0.01^{\mathrm{A}}$ & n.d. & $3.91 \pm 0.12^{\mathrm{aB}}$ & $5.01 \pm 0.08^{\mathrm{b} 1}$ & $4.01 \pm 0.08^{\mathrm{aB}}$ & $5.48 \pm 0.02^{\mathrm{b} 2}$ \\
\hline 39 & $4,7,10,13,16$-docosapentaenoic acid & n.d. & n.d. & $3.57 \pm 0.03^{\mathrm{aA}}$ & $4.56 \pm 0.03^{\mathrm{b} 1}$ & $3.58 \pm 0.05^{\mathrm{aA}}$ & $4.87 \pm 0.02^{\mathrm{b} 2}$ \\
\hline \multirow{2}{*}{37} & $4,7,10,13,16,19$-Docosahexaenoic acid & $2.32 \pm 0.02^{\mathrm{aA}}$ & $3.21 \pm 0.01^{\mathrm{b} 1}$ & $4.60 \pm 0.23^{\mathrm{aB}}$ & $5.94 \pm 0.17^{\mathrm{b} 2}$ & $4.48 \pm 0.10^{\mathrm{aB}}$ & $6.38 \pm 0.07^{\mathrm{b} 3}$ \\
\hline & Alcohols & $18.07 \pm 1.43^{a A}$ & $16.74 \pm 0.66^{a 1}$ & $27.31 \pm 1.15^{a B}$ & $25.73 \pm 0.40^{a 2}$ & $26.20 \pm 0.87^{a B}$ & $26.28 \pm 0.69^{a 2}$ \\
\hline 2 & Decanol & $0.90 \pm 0.00^{\mathrm{A}}$ & n.d. & $1.28 \pm 0.01^{\mathrm{B}}$ & n.d. & $1.34 \pm 0.00^{\mathrm{C}}$ & n.d. \\
\hline 4 & Undecanol & $0.89 \pm 0.02^{\mathrm{aA}}$ & $1.25 \pm 0.01^{\mathrm{b} 1}$ & $1.33 \pm 0.06^{\mathrm{B}}$ & n.d. & $1.40 \pm 0.01^{\mathrm{aB}}$ & $1.67 \pm 0.02^{\mathrm{b} 2}$ \\
\hline 7 & Dodecanol & $0.86 \pm 0.01^{\mathrm{aA}}$ & $1.28 \pm 0.01^{\mathrm{b} 1}$ & $1.35 \pm 0.09^{\mathrm{aB}}$ & $1.65 \pm 0.01^{\mathrm{b} 2}$ & $1.30 \pm 0.01^{\mathrm{aB}}$ & $1.75 \pm 0.08^{\mathrm{b} 2}$ \\
\hline 9 & Tridecanol & $0.87 \pm 0.01^{\mathrm{aA}}$ & $1.28 \pm 0.00^{\mathrm{b} 1}$ & $1.52 \pm 0.27^{\mathrm{aB}}$ & $1.65 \pm 0.00^{\mathrm{a} 2}$ & $1.34 \pm 0.03^{\mathrm{aB}}$ & $1.85 \pm 0.07^{\mathrm{b} 3}$ \\
\hline 10 & Tetradecanol & $1.04 \pm 0.04^{\mathrm{aA}}$ & $1.32 \pm 0.03^{\mathrm{b} 1}$ & $1.41 \pm 0.04^{\mathrm{aB}}$ & $1.61 \pm 0.01^{\mathrm{b} 2}$ & $1.47 \pm 0.02^{\mathrm{aB}}$ & $1.70 \pm 0.01^{\mathrm{b} 3}$ \\
\hline 14 & Hexadecanol & $2.96 \pm 0.48^{\mathrm{aA}}$ & $1.95 \pm 0.15^{\mathrm{b} 1}$ & $2.92 \pm 0.51^{\mathrm{aA}}$ & $2.30 \pm 0.04^{\mathrm{a} 2}$ & $3.06 \pm 0.20^{\mathrm{aA}}$ & $2.56 \pm 0.08^{\mathrm{b} 2}$ \\
\hline 22 & Octadece-9-nol & $3.49 \pm 0.53^{\mathrm{aA}}$ & $2.29 \pm 0.28^{\mathrm{b} 1}$ & $3.99 \pm 0.58^{\mathrm{aA}}$ & $3.45 \pm 0.10^{\mathrm{a} 2}$ & $4.17 \pm 0.39^{\mathrm{aA}}$ & $3.48 \pm 0.03^{\mathrm{b} 2}$ \\
\hline 24 & Octadecanol & $2.05 \pm 0.24^{\mathrm{aA}}$ & $1.88 \pm 0.09^{\mathrm{a} 1}$ & $2.26 \pm 0.25^{\mathrm{aA}}$ & $2.40 \pm 0.04^{\mathrm{a} 2}$ & $2.33 \pm 0.15^{\mathrm{aA}}$ & $2.43 \pm 0.03^{\mathrm{a} 2}$ \\
\hline 33 & Eicosanol & $0.95 \pm 0.04^{\mathrm{A}}$ & n.d. & $1.32 \pm 0.03^{\mathrm{aB}}$ & $1.62 \pm 0.00^{\mathrm{b} 1}$ & $1.32 \pm 0.01^{\mathrm{aB}}$ & n.d. \\
\hline 40 & Docosanol & n.d. & n.d. & $1.27 \pm 0.01^{\mathrm{a}}$ & $1.61 \pm 0.01^{\mathrm{b} 1}$ & n.d. & n.d. \\
\hline 47 & Hexacosanol & n.d. & n.d. & $1.26 \pm 0.00$ & n.d. & n.d. & n.d. \\
\hline 48 & Octacosanol & $1.18 \pm 0.03^{\mathrm{aA}}$ & $1.47 \pm 0.02^{\mathrm{b} 1}$ & $1.51 \pm 0.04^{\mathrm{aB}}$ & $1.89 \pm 0.07^{\mathrm{b} 2}$ & $1.55 \pm 0.01^{\mathrm{aB}}$ & $1.90 \pm 0.01^{\mathrm{b} 2}$ \\
\hline 57 & Triacontanol & $1.08 \pm 0.03^{\mathrm{aA}}$ & $1.38 \pm 0.02^{\mathrm{b} 1}$ & $1.40 \pm 0.04^{\mathrm{aB}}$ & $1.79 \pm 0.03^{\mathrm{b} 2}$ & n.d. & n.d. \\
\hline 63 & Dotriacontanol & $0.89 \pm 0.01^{\mathrm{aA}}$ & $1.26 \pm 0.00^{\mathrm{b} 1}$ & $1.30 \pm 0.03^{\mathrm{aB}}$ & $1.65 \pm 0.01^{\mathrm{b} 2}$ & $1.37 \pm 0.04^{\mathrm{aC}}$ & $1.68 \pm 0.01^{\mathrm{b} 3}$ \\
\hline 26 & 3,7,11,15-Tetramethyl-2-hexadecen-1-ol & $0.91 \pm 0.00^{\mathrm{aA}}$ & $1.39 \pm 0.06^{\mathrm{b} 1}$ & $3.21 \pm 0.30^{\mathrm{aB}}$ & $4.13 \pm 0.09^{\mathrm{b} 2}$ & $5.54 \pm 0.13^{\mathrm{aC}}$ & $7.25 \pm 0.68^{\mathrm{b} 3}$ \\
\hline & Sterols & $6.76 \pm 0.41^{a A}$ & $6.63 \pm 0.55^{a 1}$ & $11.19 \pm 1.18^{a B}$ & $11.91 \pm 0.95^{a 2}$ & $17.28 \pm 0.13^{a C}$ & $18.09 \pm 0.33^{b 3}$ \\
\hline 49 & $24 \alpha$-Methylcholest-5-en-3 $\beta$-ol & $0.31 \pm 0.01^{\mathrm{aA}}$ & $0.36 \pm 0.02^{\mathrm{b} 1}$ & $0.51 \pm 0.04^{\mathrm{aB}}$ & $0.60 \pm 0.07^{\mathrm{a} 2}$ & $0.64 \pm 0.02^{\mathrm{aC}}$ & $0.67 \pm 0.12^{\mathrm{a} 2}$ \\
\hline 51 & $24 \beta$-Ethylcholesta-5,22E-dien- $3 \beta$-ol & $0.22 \pm 0.02^{\mathrm{aA}}$ & $0.23 \pm 0.00^{\mathrm{a} 1}$ & $0.35 \pm 0.04^{\mathrm{aB}}$ & $0.32 \pm 0.01^{\mathrm{a} 1,2}$ & $0.48 \pm 0.03^{\mathrm{aC}}$ & $0.38 \pm 0.09^{\mathrm{a} 2}$ \\
\hline 52 & $24 \alpha$-Ethylcholesta-5,22E-dien- $3 \beta$-ol & $2.01 \pm 0.16^{\mathrm{aA}}$ & $1.88 \pm 0.21^{\mathrm{a} 1}$ & $4.30 \pm 0.63^{\mathrm{aB}}$ & $4.39 \pm 0.53^{\mathrm{a} 2}$ & $6.86 \pm 0.15^{\mathrm{aC}}$ & $6.81 \pm 0.25^{\mathrm{a} 3}$ \\
\hline 53 & 24-Ethyl- $\delta(22)$-coprostenol & $0.35 \pm 0.05^{\mathrm{aA}}$ & $0.31 \pm 0.01^{\mathrm{a} 1}$ & $0.55 \pm 0.06^{\mathrm{aB}}$ & $0.55 \pm 0.05^{\mathrm{a} 2}$ & $1.01 \pm 0.04^{\mathrm{aC}}$ & $1.11 \pm 0.03^{\mathrm{b} 3}$ \\
\hline 54 & $24 \alpha$-Ethylcholest-5-en- $3 \beta$-ol & $0.77 \pm 0.08^{\mathrm{aA}}$ & $0.87 \pm 0.07^{\mathrm{a} 1}$ & $0.82 \pm 0.10^{\mathrm{aAB}}$ & $1.17 \pm 0.14^{\mathrm{b} 2}$ & $0.97 \pm 0.12^{\mathrm{aB}}$ & $1.20 \pm 0.03^{\mathrm{b} 2}$ \\
\hline 55 & $4 \alpha, 24$-Dimethyl- $5 \alpha$-cholestan-3 $\beta$-ol & $0.54 \pm 0.06^{\mathrm{aA}}$ & $0.39 \pm 0.04^{\mathrm{b} 1}$ & $0.63 \pm 0.08^{\mathrm{aA}}$ & $0.68 \pm 0.02^{\mathrm{a} 2}$ & $1.06 \pm 0.09^{\mathrm{aB}}$ & $1.07 \pm 0.02^{\mathrm{a} 3}$ \\
\hline 58 & $4 \alpha$-Methyl,24-ethyl-5 $\alpha$-cholest-22E-en-3 $\beta$-ol & $0.35 \pm 0.02^{\mathrm{aA}}$ & $0.36 \pm 0.02^{\mathrm{a} 1}$ & $0.53 \pm 0.04^{\mathrm{aB}}$ & $0.55 \pm 0.04^{\mathrm{a} 2}$ & $0.82 \pm 0.01^{\mathrm{aC}}$ & $0.87 \pm 0.05^{\mathrm{a} 3}$ \\
\hline 59 & $4 \alpha$-Methyl,24-ethyl-5 $\alpha$-cholestan-3-ol & $0.40 \pm 0.03^{\mathrm{aA}}$ & $0.24 \pm 0.01^{\mathrm{b} 1}$ & $0.73 \pm 0.04^{\mathrm{aB}}$ & $0.36 \pm 0.04^{\mathrm{b} 2}$ & $0.70 \pm 0.04^{\mathrm{aB}}$ & $0.56 \pm 0.02^{\mathrm{b} 3}$ \\
\hline 61 & $4 \alpha, 24 \beta$-Dimethyl- $5 \alpha$-cholestan- $3 \beta, 4 \beta$-diol ${ }^{\mathrm{b}}$ & $0.27 \pm 0.02^{\mathrm{aA}}$ & $0.28 \pm 0.01^{\mathrm{a} 1}$ & $0.35 \pm 0.01^{\mathrm{aB}}$ & $0.41 \pm 0.01^{\mathrm{b} 2}$ & $0.48 \pm 0.03^{\mathrm{aC}}$ & $0.53 \pm 0.01^{\mathrm{b} 3}$ \\
\hline 64 & $4 \alpha$-Methyl-24 $\beta$-ethyl- $5 \alpha$-cholestan- $3 \beta, 4 \beta$-diol ${ }^{\mathrm{b}}$ & $0.48 \pm 0.07^{\mathrm{aA}}$ & $0.47 \pm 0.06^{\mathrm{a} 1}$ & $0.79 \pm 0.11^{\mathrm{aB}}$ & $0.84 \pm 0.11^{\mathrm{a} 2}$ & $1.17 \pm 0.06^{\mathrm{aC}}$ & $1.28 \pm 0.05^{\mathrm{b} 3}$ \\
\hline 56 & Unidentified Sterol & $0.58 \pm 0.05^{\mathrm{aA}}$ & $0.61 \pm 0.06^{\mathrm{a} 1}$ & $1.00 \pm 0.11^{\mathrm{aB}}$ & $1.07 \pm 0.10^{\mathrm{a} 2}$ & $2.15 \pm 0.06^{\mathrm{aC}}$ & $2.36 \pm 0.06^{\mathrm{b} 3}$ \\
\hline 62 & Unidentified Sterol & $0.49 \pm 0.03^{\mathrm{aA}}$ & $0.63 \pm 0.09^{\mathrm{b} 1}$ & $0.63 \pm 0.05^{\mathrm{aB}}$ & $0.95 \pm 0.16^{\mathrm{a} 1,2}$ & $0.93 \pm 0.03^{\mathrm{aC}}$ & $1.24 \pm 0.23^{\mathrm{a} 2}$ \\
\hline & Monoglycerides & $1.60 \pm 0.33^{A}$ & n.d. & $0.77 \pm 0.08^{B}$ & n.d. & $0.18 \pm 0.02^{C}$ & n.d. \\
\hline 35 & 2,3-Dihydroxypropyl myristate & $0.30 \pm 0.02^{\mathrm{A}}$ & n.d. & $0.44 \pm 0.06^{\mathrm{B}}$ & n.d. & $0.09 \pm 0.01^{\mathrm{C}}$ & n.d. \\
\hline 34 & 1,3-Dihydroxy-2-propanyl myristate & $0.16 \pm 0.03^{\mathrm{A}}$ & n.d. & $0.15 \pm 0.02^{\mathrm{A}}$ & n.d. & $0.05 \pm 0.01^{\mathrm{B}}$ & n.d. \\
\hline 42 & 2,3-Dihydroxypropyl palmitate & $0.61 \pm 0.16^{\mathrm{A}}$ & n.d. & $0.13 \pm 0.01^{\mathrm{B}}$ & n.d. & $0.04 \pm 0.01^{\mathrm{C}}$ & n.d. \\
\hline 41 & 1,3-Dihydroxy-2-propanyl palmitate & $0.12 \pm 0.01^{\mathrm{A}}$ & n.d. & $0.04 \pm 0.00^{\mathrm{B}}$ & n.d. & n.d. & n.d. \\
\hline 44 & 2,3-Dihydroxypropyl stearate & $0.40 \pm 0.11^{\mathrm{A}}$ & n.d. & n.d. & n.d. & n.d. & n.d. \\
\hline & Others & $1.26 \pm 0.05^{A}$ & n.d. & $0.64 \pm 0.02^{B}$ & n.d. & $0.62 \pm 0.03^{a B}$ & $0.06 \pm 0.00^{b}$ \\
\hline 46 & 2-Phenyl-1,2-propanediol & $1.08 \pm 0.04^{\mathrm{A}}$ & n.d. & n.d. & n.d. & n.d. & n.d. \\
\hline 5 & 2,6-bis(1,1-Dimethylethyl)phenol & $0.18 \pm 0.01^{\mathrm{A}}$ & n.d. & $0.35 \pm 0.01^{\mathrm{B}}$ & n.d. & $0.34 \pm 0.01^{\mathrm{aB}}$ & $0.06 \pm 0.00^{\mathrm{b}}$ \\
\hline 65 & Campesteryl glycoside & n.d. & n.d. & $0.29 \pm 0.01^{\mathrm{A}}$ & n.d. & $0.28 \pm 0.04^{\mathrm{aA}}$ & n.d. \\
\hline & Total $\left(m g g^{-1}\right)$ & $74.94 \pm 1.13^{a A}$ & $94.91 \pm 4.25^{b 1}$ & $132.32 \pm 4.52^{a B}$ & $153.59 \pm 3.52^{b 2}$ & $140.53 \pm 0.98^{a C}$ & $186.05 \pm 2.45^{b 3}$ \\
\hline
\end{tabular}




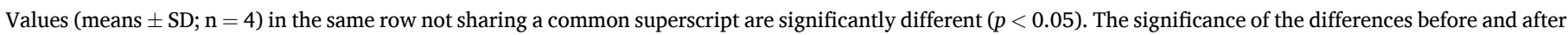

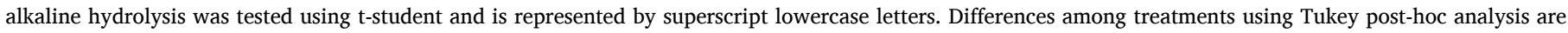

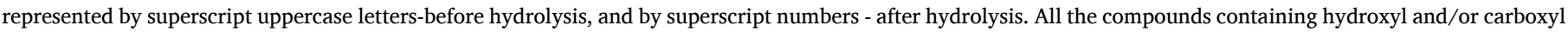

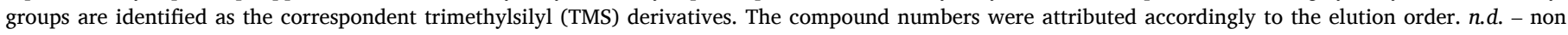
detected.

a Contains cis and trans isomers.

b Identified as the mono-TMS ether.

a)

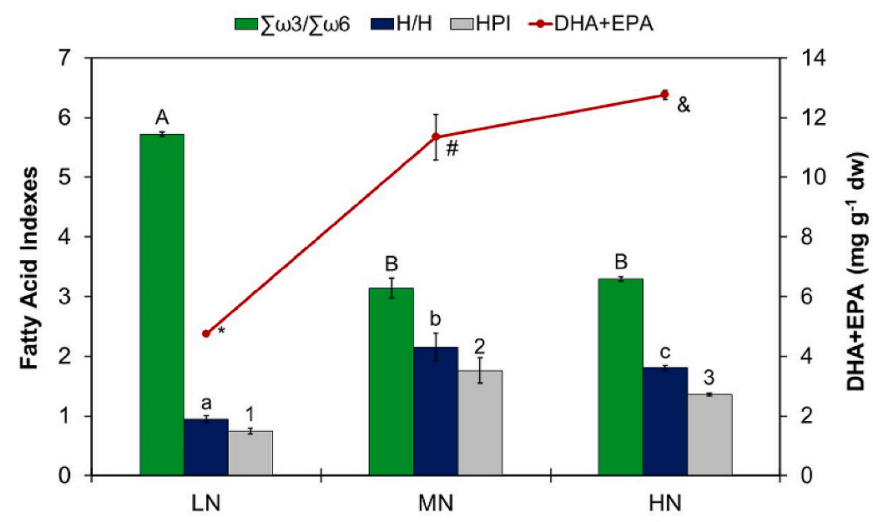

b)

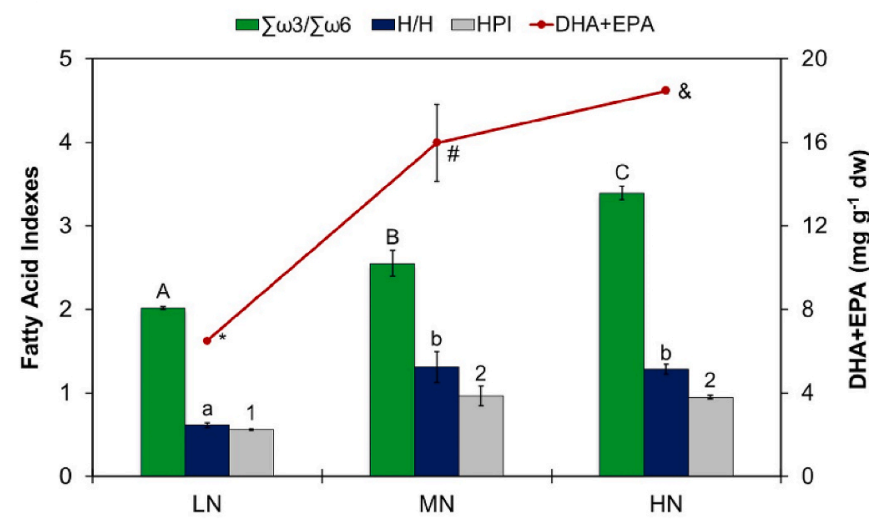

Fig. 3. Changes in fatty acid nutritional ratios from Pavlova pinguis in response to nitrogen a) before hydrolysis and b) after hydrolysis. Values are presented as mean \pm standard deviation of 4 replicates. For each variable different symbols represent significant differences among treatments $(p<0.05)$. LN - Low nitrogen; MN - Medium nitrogen; HN - High nitrogen.

indexes, the higher the value the greater the health-benefit. The highest values observed for HH (1.28-2.16) and HPI (0.95-1.76) were found at $\mathrm{MN}$ and $\mathrm{HN}$ conditions. Moreover, it is interesting to visualize that these indexes varied significantly $(p<0.05)$ with the cultivation conditions reflecting the chemoplasticity of $P$. pinguis (Fig. 3).

The forms (free or esterified) in which fatty acids are present in microalgal oils affects their absorption by animals [49]. The highest absorption of nutritionally important fatty acids is reported to occur when they are in their free chemical form [49]. However, due to their lower oxidation stability, fatty acids are often preserved in their esterified forms, comprising the most common and desirable form in edible oils [50].

This research work shows that the alkaline hydrolysis (esterified lipid hydrolysis) of $P$. pinguis affected the fatty acid classes in the following order: monounsaturated fatty acids (MUFA) $>$ SFA $>$ PUFA. The highest MUFA and SFA increase after hydrolysis was observed for the lipid extracts of $P$. pinguis grown in LN conditions (67 and 58\%, respectively). Meanwhile, the highest PUFA rise was observed for lipid extracts of $P$. pinguis grown in HN conditions (38\%). These observations suggest that the esterified lipids from $P$. pinguis mostly consist of SFA and
MUFA, and that this predominance changes in HN conditions, towards PUFA. Guihéneuf and Stengel [5] report that Pavlova lutheri responded to LN conditions by increasing the triacylglycerol fatty acid composition in $\mathrm{C} 16: 0$ and $\mathrm{C} 16: 1 \omega 7$ and decreasing the composition in EPA. In the present study, the predominant changes in fatty acids occurred for

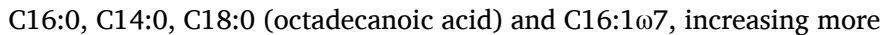
than $50 \%$ in all treatments after alkaline hydrolysis.

With a low $\sum \omega 3 / \sum \omega 6$ being often associated with a proinflammatory state, while a great $\omega 3 / \omega 6$ fatty acid ratio often attributed to an anti-inflammatory one, a balanced $\sum \omega 3 / \sum \omega 6$ fatty acid ratio, close to (1:1), is crucial for the maintenance of normal physiological processes in animals [11]. In western diet, a low $\sum \omega 3 / \sum \omega 6$ ratio $(1: 20)$ have been observed, and thus the consumption of $\omega 3$ rich sources is essential to mitigate this nutritional issue [11]. The trend displayed for $\sum \omega 3 / \sum \omega 6$ fatty acid ratio was different after and before hydrolysis among treatments (Fig. 3), especially in P. pinguis grown in LN conditions, where the $\sum \omega 3 / \sum \omega 6$ fatty acid ratio before hydrolysis (5.72) decreased by $63 \%$ after hydrolysis (2.09). Besides fatty acid composition and presence of other components (e.g. sterols), dietary lipid sources differ in their structure (triacylglycerol or phospholipid, position of fatty acid in their backbone), which, in turn, may affect its absorption, distribution, and tissue uptake of fatty acids [51]. Therefore, the previous observation indicates that at LN conditions the acylglycerols of $P$. pinguis presented a greater amount of $\omega 6$ fatty acids. This is an important remark since a higher dietary intake of $\omega 6$ fatty acids is often associated with the aggravation of inflammatory processes. At $\mathrm{HN}$ conditions $\sum \omega 3 / \sum \omega 6$ ratio remained rather stable 3.30 (before hydrolysis), and 3.39 (after hydrolysis). Moreover, for all treatments $\sum \omega 3 / \sum \omega 6$ fatty acid ratio was higher than $1(2.01-5.72)$ showing the potential of this microalga as a rich source of $\omega 3$ fatty acids.

\subsubsection{Aliphatic alcohols}

In different $\mathrm{NO}_{3}^{-}-\mathrm{N}$ levels, $P$. pinguis microalgal cells changed their aliphatic alcohol profile (Table 3). Thus, in LN conditions the dominant aliphatic alcohols were octadecen-9-ol and hexadecanol, while in MN and $\mathrm{HN}$ conditions they were octadecen-9-ol and phytol $(3,7,11,15$ tetramethyl-2-hexadecen-1-ol). From MN conditions to HN conditions, phytol levels increased by 76\%. Knowing that this compound is the main component of chlorophyll's hydrophobic tail, and that chlorophyll synthesis is closely dependent on nitrogen availability, the phytol trend suggests an increase in chlorophyll content in $P$. pinguis in HN conditions $[11,52]$. This assumption is corroborated by the chlorophylls $a$ and $c_{1}+c_{2}$ content (Table 2 ), which increased by 183 and $95 \%$, respectively, from MN to HN conditions. This observation is in accordance with Beuckels et al. [45], which suggests that in nitrogen-rich environments, microalgal cells trigger the synthesis of chlorophyll molecules, which in nutrient limiting conditions are used to fulfill cell requirements. A previous study performed by Zhu et al. [53] reported a positive correlation between PUFA and chlorophyll synthesis after nitrogen resupply, suggesting the synthesis of structural lipids (polar lipids) in chloroplast membranes. In this study, phytol (26) is positively correlated $\left(\mathrm{r}^{2}>0.90\right)$

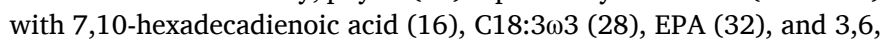
$9,12,15$-octadecapentaenoic acid (25), in the samples before and after hydrolysis (Fig. S3).

In contrast to free phytol, which can be readily converted to pristanic acid in the gastrointestinal tract and lymph, phytol linked to chlorophylls cannot be absorbed by humans [54]. Although, at supra-physiological concentrations, this alcohol may trigger the 
a)

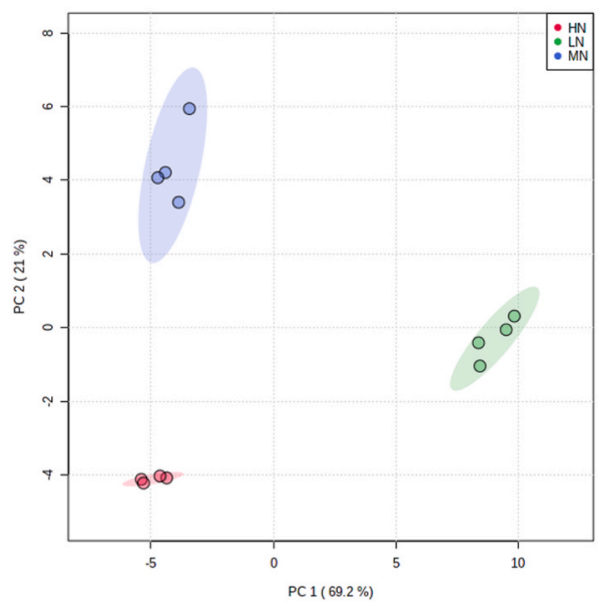

b)

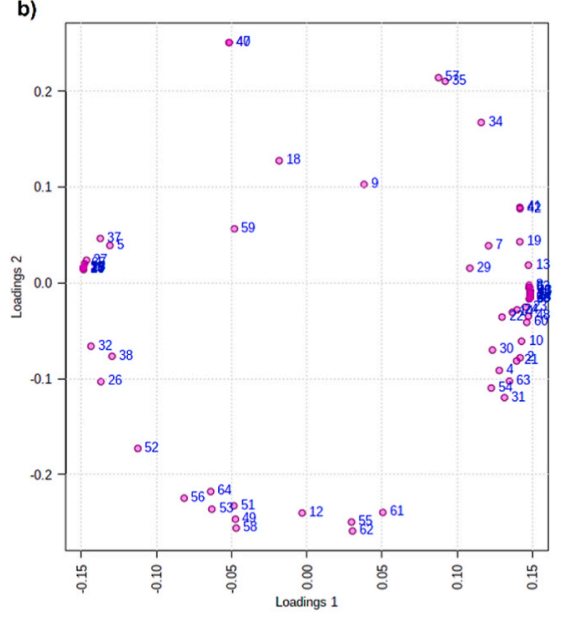

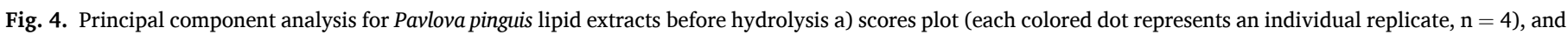
b) loadings plot. LN - low nitrogen level; MN - medium nitrogen level; HN - high nitrogen level. A description of the loadings can be seen in Table 3.

development of pathophysiological states. Phytol and its derivatives have gained interest as potential dietary compounds for cancer prevention [54]. The major dietary source of phytol is the skin of nuts, comprising $1 \mathrm{~g}$ of phytol per $100 \mathrm{~g}$ of food. In the present study, the highest free phytol content was achieved in $P$. pinguis under HN cultivation conditions, $0.55 \mathrm{~g}$ of phytol per $100 \mathrm{~g}$ of dried microalgae.

The wide range of biological properties of phytol have also drawn the attention of the pharmaceutical and biotechnological industries [55]. For instance, in cosmetics, phytol is used as a fragrance [55]. Through the hydrolysis of lipids obtained from $P$. pinguis, phytol can be concentrated up to $0.73 \mathrm{~g}$ of phytol per $100 \mathrm{~g}$ of microalgae. This value is close to other microalgae like Nannochloropsis sp. and Scenesdesmus sp. analyzed after hydrolysis, comprising 0.72 and $0.74 \mathrm{~g}$ of phytol per 100 $\mathrm{g}$ of dried biomass [56].

\subsubsection{Sterols}

A total of twelve sterol compounds were detected in $P$. pinguis subjected to different initial $\mathrm{NO}_{3}^{-}-\mathrm{N}$ levels (Fig. 2; Table 3). Different $\mathrm{NO}_{3}^{-}-N$ levels induced significant differences $(p<0.05)$ in sterol content. The dominant sterol was stigmasterol (24 $\alpha$-ethylcholesta$5,22 E$-dien-3 $\beta$-ol), which across all treatments accounted for more than $8 \%$ of total sterols. Dunaliella species are considered promising natural sources of phytosterols due to their high sterol content (0.90-1.20\%) [57]. In the present study, sterol contents varied between 0.66 and $1.81 \%$ of $P$. pinguis biomass (Table 3 ), indicating that this microalga is a potential source for phytosterol for industrial exploitation.

Through the analysis of Table 3 , it is possible to observe that HN conditions induced an increase, of $P$. pinguis microalgal cell sterol content among treatments, increasing up to $54 \%$ from MN to HN. Meanwhile, $P$. pinguis grown in LN conditions had a decrease in sterol content, down to $44 \%$ from MN to LN. In opposition to fatty acids, microalgal sterols are known to be more stable in changing environmental conditions [58]. However, differences in phytosterol synthesis have been reported for Pavlova species with varying UV-C radiation, salinity and growth phase $[57,59,60]$.

The lowest sterol content values reported in this research work, for $P$. pinguis at LN level, are similar to Scenedesmus quadricauda, Cryptomonas ovata and Cyclotella meneghiniana, where nutrient limitation strategies resulted in a decrease of total sterol content [61]. This seems to indicate that $P$. pinguis responded to $\mathrm{LN}$ conditions by down-regulating the enzymes involved in sterol synthesis and/or by reducing sterol incorporation in plasma membranes [61].

The stigmasterol proportion increased from 28 to $38 \%$ of the total sterol content as the $\mathrm{NO}_{3}^{-}-\mathrm{N}$ level increased, while $\beta$-sitosterol (24 $\alpha$ ethylcholest-5-en-3 $\beta$-ol) decreased from 13 to $6 \%$ of total sterols (Table 3). In the phytosterol biosynthetic pathway of Dunaliella tertioleta, $\beta$-sitosterol is the precursor of stigmasterol [62]. Thus, the observed opposite trend might suggest that $P$. pinguis microalgal cells transform $\beta$-sitosterol to stigmasterol towards high $\mathrm{NO}_{3}^{-}-\mathrm{N}$ levels. Through Table 3 it is possible to observe that $P$. pinguis total sterols did not increase with alkaline hydrolysis, which indicates that the detected sterols were mainly free sterols. This finding is in accordance with Volkman [58], which reported that free sterols predominate in microalgae.

Plant phytosterols have been widely used as functional ingredients in food industry due to their low cholesterol abilities [57,59]. From microalgal lipid composition, sterols are an underexploited resource for food industry. Thus, the great amounts of phytosterols verified for $P$. pinguis towards HN conditions should be further studied as a sustainable source of phytosterols for food industry.

\subsubsection{Monoglycerides and other compounds}

In LN conditions, monoglycerides were positively influenced by increasing $\mathrm{NO}_{3}^{-}-\mathrm{N}$ levels, nearly doubling with respect to MN conditions (Table 3 ). An opposite trend was verified by $P$. pinguis microalgal cells grown in HN conditions, where monoglycerides decreased by $77 \%$ (Table 3). The monoglycerides before hydrolysis were those with acyl bonds to C16:0, C14:0 and C18:0 (Table 3), which are included in the fatty acids where the highest increase after alkaline hydrolysis treatment occurred (Table 3). However, small levels of monoglycerides cannot explain the increase in fatty acids after alkaline hydrolysis and indicate that these compounds are present mainly as other acyl-glycerides in $P$. pinguis microalgal cells. For instance, triacylglycerols are cells' energy reservoirs, whose production is enhanced under unfavorable growth conditions [63]. In nutrient limiting conditions, microalgae are known to redirect photosynthetic carbon fixation towards triacylglycerol accumulation [64].

Campesteryl glycoside was detected in $P$. pinguis microalgal cells $\left(0.28-0.29 \mathrm{mg} \mathrm{g}^{-1}\right)$ at $\mathrm{MN}$ and $\mathrm{HN}$ conditions before hydrolysis (Table 3). Increasing $\mathrm{NO}_{3}^{-}-N$ concentration in $P$. pinguis growth medium enhances its production. The observed steryl glycoside was also reported for Pavlova viridis in an amount of $0.52 \mathrm{mg} \mathrm{g}^{-1}$ [65]. These amphipathic molecules have an enhanced solubility in food products when compared to free phytosterols which, in turn, make them easier to add to food products as functional ingredients to lower blood cholesterol [65]. 
a)

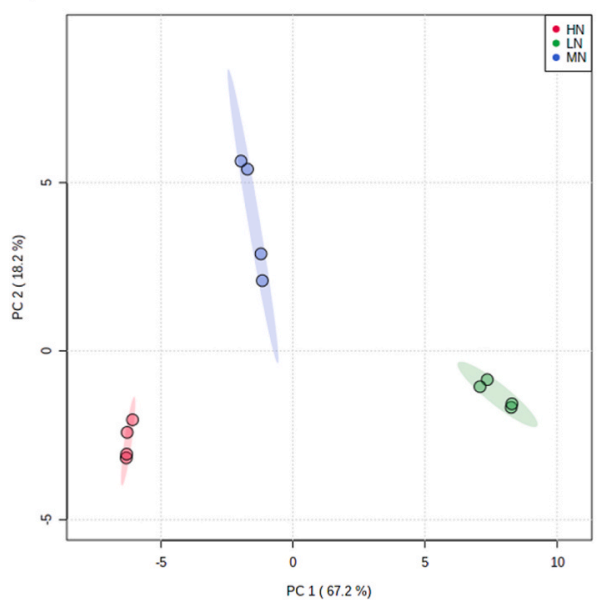

b)

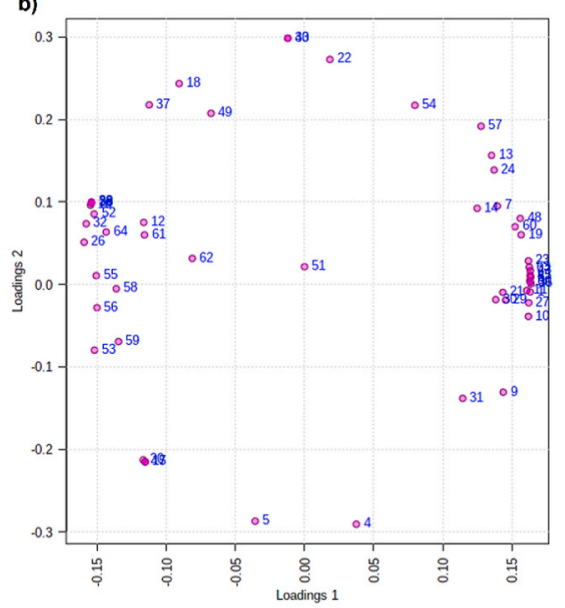

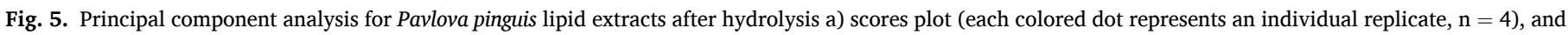
b) loadings plot. LN - low nitrogen level; MN - medium nitrogen level; HN - high nitrogen level. A description of the loadings can be seen in Table 3.
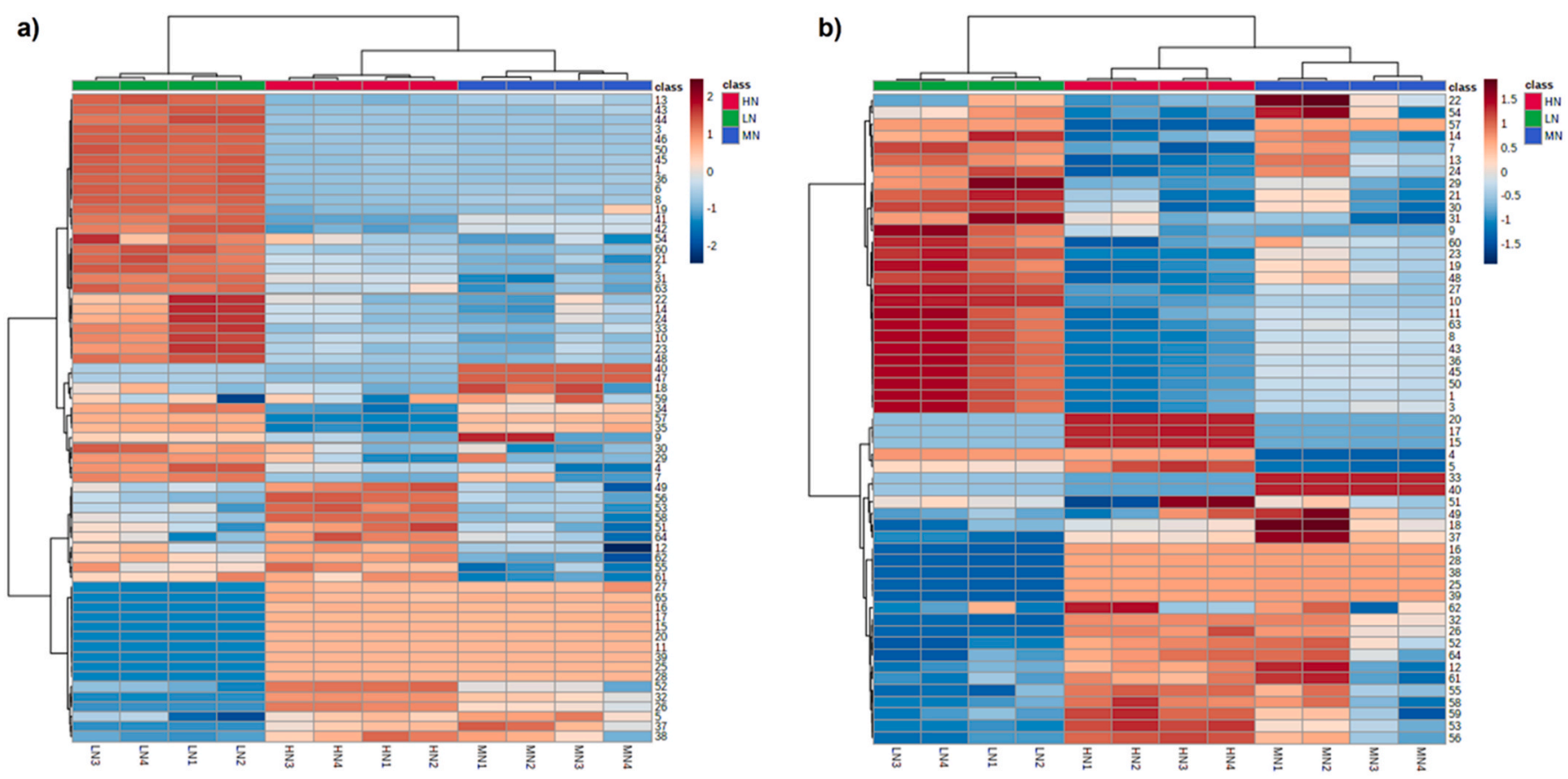

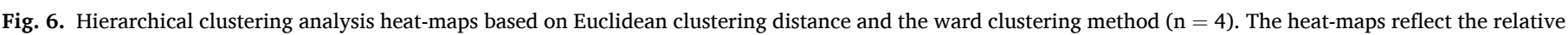

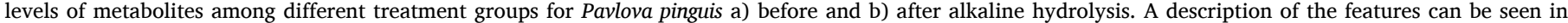

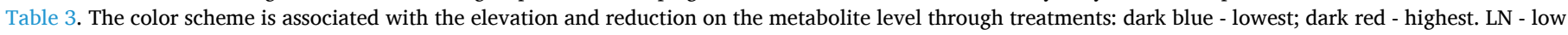

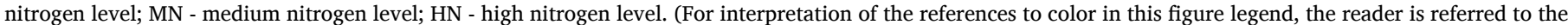
Web version of this article.)

\subsection{Modulating lipids composition by $\mathrm{NO}_{3}^{-}-\mathrm{N}$ supplementation}

Principal component analysis (PCA) showed a clear separation between the lipidomes of the LN, MN and HN groups in the scores plot before hydrolysis (Fig. 4a). The loadings distribution (Fig. 4b) enabled the observation of the metabolites responsible for the discrimination pattern. Therefore, before hydrolysis, principal components described $90 \%$ of the variation. PC1 separated the LN from the MN and HN groups, while PC2 separated the MN and HN groups. The first distinction was primarily due to SFA, monoglycerides, some specific alcohols like decanol (2), tetradecanol (10), eicosanol (33), and octacosanol (48), and the fatty acid 9-hexadecenoic acid (18), positively correlated with PC1, while the second was mostly due to sterols (negatively correlated with both PC1 and PC2).

SFA and MUFA are the best ingredients for biodiesel production [66]. The abundance of these compounds is responsible for the key properties that reflect the quality of biofuel $[64,66]$. Higher levels of SFA and MUFA contribute to a higher cetane number, decreased $\mathrm{NO}_{\mathrm{x}}$ emissions, shorter ignition delay time, oxidative stability, and low-temperature fluidity $[64,66]$. Thus, and according to the multivariate analysis, the best lipid profile for this purpose was recorded for $P$. pinguis cultivated in LN conditions (positively correlated with PC1).

Phytosterols have several industrial applications such as: $i$ ) pharmaceutical (raw materials for therapeutic steroids), ii) nutraceutical 
(food additive, cholesterol lowering properties and cardiovascular health maintenance), and iii) cosmetics (additive in creams and lipsticks) $[57,59]$. Thus, and according to the multivariate analysis, HN conditions are a useful tool for inducing sterol production in $P$. pinguis.

The variability explained by the principal components after hydrolysis (Fig. 5a, 85\%) was close to the one obtained before hydrolysis, and so was the clustering pattern of the different groups as compared with the previous PCA. However, the loadings contribution for cluster discrimination was different (Fig. 5b). Thus, for PC1 the main loadings contributing positively for LN separation were SFA, 9-tetradecenoic (11), 7-hexadecenoic (19), and 9,12-octadecadienoic acids (27), and the alcohols tetradecanol (10), octacosanol (48) and dotriacontanol (63). Meanwhile, for PC2 they were polyunsaturated C16 fatty acids 7,12-hexadienoic acid (15); 7,10,13-hexadecatrienoic acid (17), and methyl-4,7,10,13-hexadecatetraenoate (20), undecanol (4), and 2,6-bis (1,1-dimethylethyl)phenol (5).

Shen et al. [67] studied the relationship between the characteristic fatty acid and triacylglycerol content in microalgae, concluding that PUFA are often abundant in polar lipids (glycolipids and phospholipids) rather than in triacylglycerols. For instance, C16:4 and C16:3 comprise the bulk of fatty acids in monogalactosyldiacylglycerols for Chlamydomonas reinhardtii and the model plant Arabidopsis thaliana, respectively [67]. Thus, the correlation of $P$. pinguis cultivated in $\mathrm{HN}$ conditions with the polyunsaturated C16 fatty acids after hydrolysis demonstrated in Fig. 5 might be due to higher levels of glycolipids. When supplying dietary PUFA for fish hatcheries, fatty acids in polar lipids are nutritionally more available than those in neutral lipids, making the HN condition suitable for increasing dietary intake for nutraceuticals and aquaculture [49]. Moreover, SFA and MUFA esterified into glycerol-based neutral lipids (like mono-, di-, and triacylglycerols) can be converted to biodiesel [64], which again makes $P$. pinguis grown in the LN treatment the most promising candidate for biodiesel or fuel production.

The heat maps (Fig. 6) allowed the visualization of clusters of samples (columns) and features (rows) according to the hierarchical clustering analysis. The data matrix displays the normalized data organized according to similarity. It is possible to observe that the $\mathrm{LN}$ group was furthest from the MN group, indicating that $\mathrm{NO}_{3}^{-}-\mathrm{N}$ limitation presented the most considerable perturbation of the lipidome. This group showed opposite trends compared with the other clusters for most metabolites. Moreover, through the heat maps it was possible to observe that $P$. pinguis cultured in both $\mathrm{MN}$ and $\mathrm{HN}$ conditions had greater levels of nutritionally important fatty acids (PUFA) and sterols.

\section{Conclusions}

According to the field of application different levels of $\mathrm{NO}_{3}^{-}-\mathrm{N}$ are recommended. Thus, higher $\mathrm{NO}_{3}^{-}-\mathrm{N}$ levels are recommended for chlorophyll, carotenoid, and high-value lipid accumulation with applications in nutraceutics, pharmaceutics, and cosmetics, while low $\mathrm{NO}_{3}^{-}-$ $N$ levels should be used for enhancing $P$. pinguis lipid quality for biodiesel. Since the knowledge of the effect of other nutrients besides nitrogen on $P$. pinguis high-value lipids accumulation is scarce, further studies should be performed to optimize culture growth conditions and fully exploit $P$. pinguis potential for microalgal-based industries. Moreover, given the great diversity and versatility found for $P$. pinguis lipid extracts across treatments, more research should focus on the potential of the different types of lipids derived from microalgae, including their functional activity, synergistic effects, and biosynthetic pathways.

\section{Statement of informed consent, human/animal rights}

No conflicts, informed consent, or human or animal rights are applicable to this study.

\section{Declarations of interest}

None.

\section{Author statement}

T.F. and N.C. contributed to the conception and design of the study. T.F. executed the experiment, analyzed, and interpreted the data, and wrote the manuscript. N.C. made possible the execution of the experiment through providing administrative and financial support, supervising the experiment, and making the critical revisions regarding important intellectual content of the manuscript. All authors read and approved the final manuscript.

\section{Acknowledgments}

This research was partially supported by Portuguese funds through the Foundation for Science and Technology, within the scope of UIDB/ $04423 / 2020$ and UIDP/04423/2020, and the European Territorial Cooperation Programme PCT-MAC 2014-2020, through project REBECA-CCT (MAC/1.1.B/269). Tomásia Fernandes was financially supported by a doctoral grant from Regional Agency for Development of Research, Technology and Innovation of Madeira, Project M1420-095369-FSE-000002.

\section{Appendix A. Supplementary data}

Supplementary data to this article can be found online at https://doi. org/10.1016/j.biombioe.2022.106341.

\section{References}

[1] A.K. Koyande, K.W. Chew, K. Rambabu, Y. Tao, D.T. Chu, P.L. Show, Microalgae: a potential alternative to health supplementation for humans, Food Sci. Hum. Wellness. 8 (2019) 16-24, https://doi.org/10.1016/j.fshw.2019.03.001.

[2] M. Bussa, A. Eisen, C. Zollfrank, H. Röder, Life cycle assessment of microalgae products: state of the art and their potential for the production of polylactid acid, J. Clean. Prod. 213 (2019) 1299-1312, https://doi.org/10.1016/j. jclepro.2018.12.048.

[3] L. Xin, H. Hong-ying, G. Ke, S. Ying-xue, Effects of different nitrogen and phosphorus concentrations on the growth, nutrient uptake, and lipid accumulation of a freshwater microalga Scenedesmus sp, Bioresour. Technol. 101 (2010) 5494-5500, https://doi.org/10.1016/j.biortech.2010.02.016.

[4] P.G. Falkowski, J. Raven, Making cells, in: P.G. Falkowski, J.A. Raven (Eds.), Aquat. Photosynth., Blackwell science, United States of America, 1997, pp. 228-262.

[5] F. Guihéneuf, D.B. Stengel, LC-PUFA-enriched oil production by microalgae: accumulation of lipid and triacylglycerols containing n-3 LC-PUFA is triggered by nitrogen limitation and inorganic carbon availability in the marine haptophyte Pavlova lutheri, Mar. Drugs 11 (2013) 4246-4266, https://doi.org/10.3390/ md11114246.

[6] H.T. Wang, C.H. Yao, J.N. Ai, X.P. Cao, S. Xue, W. liang Wang, Identification of carbohydrates as the major carbon sink of the marine microalga Isochrysis zhangjiangensis (Haptophyta) and optimization of its productivity by nitrogen manipulation, Bioresour. Technol. 171 (2014) 298-304, https://doi.org/10.1016/ j.biortech.2014.08.090.

[7] X. Wang, H.K. Fosse, K. Li, M.S. Chauton, O. Vadstein, K.I. Reitan, Influence of nitrogen limitation on lipid accumulation and EPA and DHA content in four marine microalgae for possible use in aquafeed, Front. Mar. Sci. 6 (2019) 1-10, https:// doi.org/10.3389/fmars.2019.00095.

[8] S.P. Slocombe, Q. Zhang, M. Ross, A. Anderson, N.J. Thomas, Á. Lapresa, C. RadMenéndez, C.N. Campbell, K.D. Black, M.S. Stanley, J.G. Day, Unlocking nature's treasure-chest: screening for oleaginous algae, Sci. Rep. 5 (2015) 1-17, https://doi. org/10.1038/srep09844.

[9] J. Benemann, Microalgae for biofuels and animal feeds, Energies 6 (2013) 5869-5886, https://doi.org/10.3390/en6115869.

[10] E. Ponis, I. Probert, B. Véron, J.R. Le Coz, M. Mathieu, R. Robert, Nutritional value of six Pavlovophyceae for Crassostrea gigas and Pecten maximus larvae, Aquaculture 254 (2006) 544-553, https://doi.org/10.1016/j. aquaculture.2005.11.017.

[11] T. Fernandes, A. Martel, N. Cordeiro, Exploring Pavlova pinguis chemical diversity: a potentially novel source of high value compounds, Sci. Rep. 10 (2020) 339, https://doi.org/10.1038/s41598-019-57188-y.

[12] S. Vidyashankar, P.D. Daris, K.G. Mallikarjuna, R. Sarada, Microalgae as a source of nutritional and therapeutic metabolites, in: M.W. Siddiqui, K. Prasad (Eds.), Plant Second. Metab. Biol. Ther. Significance, CRC Press Taylor \& Francis, 2017. http: 
/syndetics.com/index.aspx/?isbn=9781771883566/summary.html\&clie $\mathrm{nt}=\mathrm{vtu} \& \mathrm{type}=\mathrm{rw} 12$.

[13] P. Ranadheer, R. Kona, R.V. Sreeharsha, S. Venkata Mohan, Non-lethal nitrate supplementation enhances photosystem II efficiency in mixotrophic microalgae towards the synthesis of proteins and lipids, Bioresour. Technol. 283 (2019) 373-377, https://doi.org/10.1016/j.biortech.2019.03.089.

[14] C.N. Eze, H. Aoyagi, J.C. Ogbonna, Simultaneous accumulation of lipid and carotenoid in freshwater green microalgae Desmodesmus subspicatus LC172266 by nutrient replete strategy under mixotrophic condition, Kor. J. Chem. Eng. 37 (2020) 1522-1529, https://doi.org/10.1007/s11814-020-0564-8.

[15] J.M. Cho, Y.K. Oh, W.K. Park, Y.K. Chang, Effects of nitrogen supplementation status on co2 biofixation and biofuel production of the promising microalga chlorella sp. ABC-001, J. Microbiol. Biotechnol. 30 (2020) 1235-1243, https://doi. org/10.4014/jmb.2005.05039.

[16] A.E. Rodrigues-Sousa, I.V.O. Nunes, A.B. Muniz-Junior, J.C.M. Carvalho, L. C. Mejia-da-Silva, M.C. Matsudo, Nitrogen supplementation for the production of Chlorella vulgaris biomass in secondary effluent from dairy industry, Biochem. Eng. J. 165 (2021), https://doi.org/10.1016/j.bej.2020.107818.

[17] J. Junpeng, C. Xupeng, Y. Miao, X. Song, Monogalactosyldiacylglycerols with high PUFA content from microalgae for value-added products, Appl. Biochem. Biotechnol. 190 (2020) 1212-1223, https://doi.org/10.1007/s12010-019-03159-

[18] D. Morales-Sánchez, P.S.C. Schulze, V. Kiron, R.H. Wijffels, Production of carbohydrates, lipids and polyunsaturated fatty acids (PUFA) by the polar marine microalga Chlamydomonas malina RCC2488, Algal Res. 50 (2020), https://doi. org/10.1016/j.algal.2020.102016.

[19] M.A. Angel-Dapa, G.E. Nava-Gómez, L. López-Galindo, E. Carpizo-Ituarte, S. Castellanos-Martínez, G. Correa-Reyes, Z. Garcia-Esquivel, Effect of larval density and algal concentration on growth, survival and feeding rates of the scallop Nodipecten subnodosus (Sowerby, 1835), Aquacult. Res. 52 (2021) 4776-4785, https://doi.org/10.1111/are.15311.

[20] S.K.D. Pease, K.S. Reece, J. O'Brien, P.L.M. Hobbs, J.L. Smith, Oyster hatchery breakthrough of two HABs and potential effects on larval eastern oyster (Crassostrea virginica), Harmful Algae 101 (2021), https://doi.org/10.1016/j. hal.2020.101965.

[21] R.R. Guillard, J.H. Ryther, Studies of marine planktonic diatoms. I. Cyclotella nana Hustedt, and Detonula confervacea (cleve) Gran, Can. J. Microbiol. 8 (1962) 229-239, https://doi.org/10.1139/m62-029.

[22] R.R.L. Guillard, Culture of phytoplankton for feeding marine invertebrates, in: W. L. Smith, M.H. Chanley (Eds.), Cult. Mar. Invertebr. Anim., Springer, Boston, 1975, pp. 29-60, https://doi.org/10.1007/978-1-4615-8714-93.

[23] R. Samiee-Zafarghandi, J. Karimi-Sabet, M.A. Abdoli, A. Karbassi, Increasing microalgal carbohydrate content for hydrothermal gasification purposes, Renew. Energy 116 (2018) 710-719, https://doi.org/10.1016/j.renene.2017.10.020.

[24] C. Wan, F.W. Bai, X.Q. Zhao, Effects of nitrogen concentration and media replacement on cell growth and lipid production of oleaginous marine microalga Nannochloropsis oceanica DUT01, Biochem. Eng. J. 78 (2013) 32-38, https://doi. org/10.1016/j.bej.2013.04.014

[25] Y. Chen, S. Vaidyanathan, Simultaneous assay of pigments, carbohydrates, protein and lipids in microalgae, Anal. Chim. Acta 776 (2013) 31-40, https://doi.org/ 10.1016/j.aca.2013.03.005.

[26] S.W. Jeffrey, G.F. Humphrey, New spectrophotometric equations for determining chlorophylls a, b, c1 and c2 in higher plants, algae and natural phytoplankton, Biochem. Physiol. Pflanz. (BPP) 167 (1975) 191-194, https://doi.org/10.1016/ s0015-3796(17)30778-3.

[27] E.G. Bligh, W.J. Dyer, A rapid method of total lipid extraction and purification, Can. J. Biochem. Physiol. 37 (1959) 911-917, https://doi.org/10.1139/059-099.

[28] T. Fernandes, I. Fernandes, C.A.P. Andrade, N. Cordeiro, Marine microalgae growth and carbon partitioning as a function of nutrient availability, Bioresour. Technol. 214 (2016) 541-547, https://doi.org/10.1016/j.biortech.2016.05.001.

29] S.A.O. Santos, C. Vilela, C.S.R. Freire, M.H. Abreu, S.M. Rocha, A.J.D. Silvestre, Chlorophyta and Rhodophyta macroalgae: a source of health promoting phytochemicals, Food Chem. 183 (2015) 122-128, https://doi.org/10.1016/j. foodchem.2015.03.006.

[30] W.W. Christie, The lipid web. https://www.lipidmaps.org/resources/lipidweb/i ndex.php?page=index.html, 2021. (Accessed 4 October 2021).

[31] A. Gutiérrez, I.M. Rodríguez, J.C. del Río, Chemical composition of lipophilic extractives from sisal (Agave sisalana) fibers, Ind. Crop. Prod. 28 (2008) 81-87, https://doi.org/10.1016/j.indcrop.2008.01.008.

[32] F.O. Silvério, L.C.A. Barbosa, A.J.D. Silvestre, D. Piló-Veloso, J.L. Gomide, Comparative study on the chemical composition of lipophilic fractions from three wood tissues of Eucalyptus species by gas chromatography-mass spectrometry analysis, J. Wood Sci. 53 (2007) 533-540, https://doi.org/10.1007/s10086-007 0901-0.

[33] J. Santos-Silva, R.J.B. Bessa, F. Santos-Silva, Effect of genotype, feeding system and slaughter weight on the quality of light lambs. II. Fatty acid composition of meat, Livest. Prod. Sci. 77 (2002) 187-194, https://doi.org/10.1016/S0301-6226(02) 00059-3.

[34] J. Chen, H. Liu, Nutritional indices for assessing fatty acids: a mini-review, Int. J. Mol. Sci. 21 (2020) 1-24, https://doi.org/10.3390/ijms21165695.

[35] J. Xia, D.S. Wishart, Using MetaboAnalyst 3.0 for comprehensive metabolomics data analysis, Curr. Protoc. Bioinform. 55 (2016), https://doi.org/10.1002/ cpbi.11, 14.10.1- 14.10.91.

[36] R. Sivaramakrishnan, A. Incharoensakdi, Enhancement of total lipid yield by nitrogen, carbon, and iron supplementation in isolated microalgae, J. Phycol. 53 (2017) 855-868, https://doi.org/10.1111/jpy.12549.
[37] N.A. Zakariah, N.A. Rahman, N.R.N. Him, Effects of nitrogen supplementation in replete condition on the biomass yield and microalgae properties of chlorella sorokiniana, ARPN J. Eng. Appl. Sci. 12 (2017) 3290-3298.

[38] M.J. Zarrinmehr, O. Farhadian, F.P. Heyrati, J. Keramat, E. Koutra, M. Kornaros, E. Daneshvar, Effect of nitrogen concentration on the growth rate and biochemical composition of the microalga, Isochrysis galbana, Egypt, J. Aquat. Res. 46 (2020) 153-158, https://doi.org/10.1016/j.ejar.2019.11.003.

[39] Z. Gojkovic, Y. Lu, L. Ferro, A. Toffolo, C. Funk, Modeling biomass production during progressive nitrogen starvation by North Swedish green microalgae, Algal Res. 47 (2020), https://doi.org/10.1016/j.algal.2020.101835.

[40] R. Whitton, A. Le Mével, M. Pidou, F. Ometto, R. Villa, B. Jefferson, Influence of microalgal $\mathrm{N}$ and $\mathrm{P}$ composition on wastewater nutrient remediation, Water Res. 91 (2016) 371-378, https://doi.org/10.1016/j.watres.2015.12.054.

[41] C. Tantanasarit, A.J. Englande, S. Babel, Nitrogen, phosphorus and silicon uptake kinetics by marine diatom Chaetoceros calcitrans under high nutrient concentrations, J. Exp. Mar. Biol. Ecol. 446 (2013) 67-75, https://doi.org/ 10.1016/j.jembe.2013.05.004.

[42] Y. Collos, M.Y. Siddiqi, M.Y. Wang, A.D.M. Glass, P.J. Harrison, Nitrate uptake kinetics by two marine diatoms using the radioactive tracer 13N, J. Exp. Mar. Biol. Ecol. 163 (1992) 251-260, https://doi.org/10.1016/0022-0981(92)90053-D.

[43] E. Daneshvar, C. Santhosh, E. Antikainen, A. Bhatnagar, Microalgal growth and nitrate removal efficiency in different cultivation conditions: effect of macro and micronutrients and salinity, J. Environ. Chem. Eng. 6 (2018) 1848-1854, https:// doi.org/10.1016/j.jece.2018.02.033.

[44] H. Fan, K. Wang, C. Wang, F. Yu, X. He, J. Ma, X. Li, A comparative study on growth characters and nutrients removal from wastewater by two microalgae under optimized light regimes, Environ. Technol. Innovat. 19 (2020), https://doi. org/10.1016/j.eti.2020.100849.

[45] A. Beuckels, E. Smolders, K. Muylaert, Nitrogen availability influences phosphorus removal in microalgae-based wastewater treatment, Water Res. 77 (2015) 98-106, https://doi.org/10.1016/j.watres.2015.03.018.

[46] R. Sathasivam, J.S. Ki, A review of the biological activities of microalgal carotenoids and their potential use in healthcare and cosmetic industries, Mar. Drugs 16 (2018), https://doi.org/10.3390/md16010026.

[47] R. Huerlimann, E.J. Steinig, H. Loxton, K.R. Zenger, D.R. Jerry, K. Heimann, Effects of growth phase and nitrogen starvation on expression of fatty acid desaturases and fatty acid composition of Isochrysis aff. galbana (TISO), Gene 545 (2014) 36-44, https://doi.org/10.1016/j.gene.2014.05.009.

[48] A. Sukenik, Ecophysiological considerations in the optimization of eicosapentaenoic acid production by Nannochloropsis sp. (Eustigmatophyceae), Bioresour, Technol. 35 (1991) 263-269, https://doi.org/10.1016/0960-8524(91) 90123-2.

[49] F.C. Wang, A.G. Marangoni, Advances in the application of food emulsifier $\alpha$-gel phases: saturated monoglycerides, polyglycerol fatty acid esters, and their derivatives, J. Colloid Interface Sci. 483 (2016) 394-403, https://doi.org/ 10.1016/j.jcis.2016.08.012.

[50] T.J. Lin, S.W. Chen, A.C. Chang, Enrichment of n-3 PUFA contents on triglycerides of fish oil by lipase-catalyzed trans-esterification under supercritical conditions, Biochem. Eng. J. 29 (2006) 27-34, https://doi.org/10.1016/j.bej.2005.02.035.

[51] M. Ramírez, L. Amate, A. Gil, Absorption and distribution of dietary fatty acids from different sources, Early Hum. Dev. 65 (2001) 95-101, https://doi.org/ 10.1016/S0378-3782(01)00211-0.

[52] M. Giordano, J.A. Raven, Nitrogen and sulfur assimilation in plants and algae, Aquat. Bot. 118 (2014) 45-61, https://doi.org/10.1016/j.aquabot.2014.06.012.

[53] S. Zhu, P. Feng, J. Feng, J. Xu, Z. Wang, J. Xu, Z. Yuan, The roles of starch and lipid in Chlorella sp. during cell recovery from nitrogen starvation, Bioresour. Technol. 247 (2018) 58-65, https://doi.org/10.1016/j.biortech.2017.08.120.

[54] G. Bobe, Z. Zhang, R. Kopp, M. Garzotto, J. Shannon, Y. Takata, Phytol and its metabolites phytanic and pristanic acids for risk of cancer: current evidence and future directions, Eur. J. Cancer Prev. (2020) 191-200, https://doi.org/10.1097/ CEJ.0000000000000534.

[55] M.T. Islam, E.S. Ali, S.J. Uddin, S. Shaw, M.A. Islam, M.I. Ahmed, M. Chandra Shill, U.K. Karmakar, N.S. Yarla, I.N. Khan, M.M. Billah, M.D. Pieczynska, G. Zengin, C. Malainer, F. Nicoletti, D. Gulei, I. Berindan-Neagoe, A. Apostolov, M. Banach, A. W.K. Yeung, A. El-Demerdash, J. Xiao, P. Dey, S. Yele, A. Jóźwik, N. Strzałkowska, J. Marchewka, K.R.R. Rengasamy, J. Horbańczuk, M.A. Kamal, M.S. Mubarak, S. K. Mishra, J.A. Shilpi, A.G. Atanasov, Phytol: a review of biomedical activities, Food Chem. Toxicol. 121 (2018) 82-94, https://doi.org/10.1016/j. fct.2018.08.032.

[56] L. Yao, J.A. Gerde, S.L. Lee, T. Wang, K.A. Harrata, Microalgae lipid characterization, J. Agric. Food Chem. 63 (2015) 1773-1787, https://doi.org/ 10.1021/if5050603.

[57] F. Ahmed, P.M. Schenk, UV-C radiation increases sterol production in the microalga Pavlova lutheri, Phytochemistry 139 (2017) 25-32, https://doi.org/ 10.1016/j.phytochem.2017.04.002.

[58] J.K. Volkman, Sterols in microalgae, in: M.A. Borowitzka, J. Beardall, J.A. Raven (Eds.), Dev. Appl. Phycol. Physiol. Microalgae, sixth ed., Springer, Cham, Switzerland, 2016, pp. 485-505.

[59] F. Ahmed, W. Zhou, P.M. Schenk, Pavlova lutheri is a high-level producer of phytosterols, Algal Res. 10 (2015) 210-217, https://doi.org/10.1016/j. algal.2015.05.013.

[60] Z. Xu, X. Yan, L. Pei, Q. Luo, J. Xu, Changes in fatty acids and sterols during batch growth of Pavlova viridis in photobioreactor, J. Appl. Phycol. 20 (2008) 237-243, https://doi.org/10.1007/s10811-007-9230-3.

[61] M. Piepho, D. Martin-Creuzburg, A. Wacker, Phytoplankton sterol contents vary with temperature, phosphorus and silicate supply: a study on three freshwater 
species, Eur. J. Phycol. 47 (2012) 138-145, https://doi.org/10.1080/ 09670262.2012.665484.

[62] B.Z. Haznedaroglu, H. Rismani-Yazdi, F.C.T. Allnutt, D. Reeves, J. Peccia, Algal biorefinery for high-value platform chemicals, in: S.K. Brar, S.J. Sarma, K. Pakshirajan (Eds.), Platf. Chem. Biorefinery, Elsevier, 2016, pp. 333-360.

[63] R. Huerlimann, R. de Nys, K. Heimann, Growth, lipid content, productivity, and fatty acid composition of tropical microalgae for scale-up production, Biotechnol. Bioeng. 107 (2010) 245-257, https://doi.org/10.1002/bit.22809.

[64] S.K. Ratha, R. Prasanna, R.B.N. Prasad, C. Sarika, D.W. Dhar, A.K. Saxena, Modulating lipid accumulation and composition in microalgae by biphasic nitrogen supplementation, Aquaculture 392-395 (2013) 69-76, https://doi.org/ 10.1016/j.aquaculture.2013.02.004.
[65] S. Yu, Y. Zhang, Y. Ran, W. Lai, Z. Ran, J. Xu, C. Zhou, X. Yan, Characterization of steryl glycosides in marine microalgae by gas chromatography-triple quadrupole mass spectrometry (GC-QQQ-MS), J. Sci. Food Agric. 98 (2018) 1574-1583, https://doi.org/10.1002/jsfa.8629.

[66] L. Zhang, J. Cheng, H. Pei, J. Pan, L. Jiang, Q. Hou, F. Han, Cultivation of microalgae using anaerobically digested effluent from kitchen waste as a nutrient source for biodiesel production, Renew. Energy 115 (2018) 276-287, https://doi. org/10.1016/j.renene.2017.08.034.

[67] P.L. Shen, H.T. Wang, Y.F. Pan, Y.Y. Meng, P.C. Wu, S. Xue, Identification of characteristic fatty acids to quantify triacylglycerols in microalgae, Front. Plant Sci. 7 (2016), https://doi.org/10.3389/fpls.2016.00162. 